\title{
Prediction of Erosion-Prone Areas in the Catchments of Big Lowland Rivers: Implementation of Maximum Entropy Modelling-Using the Example of the Lower Vistula River (Poland)
}

\author{
Marta Brzezińska *(D), Dawid Szatten (D) and Zygmunt Babiński \\ Department of Inland Waterways Revitalization, Institute of Geography, Kazimierz Wielki University, \\ 85-064 Bydgoszcz, Poland; szatten@ukw.edu.pl (D.S.); zygmunt.babinski@ukw.edu.pl (Z.B.) \\ * Correspondence: m.brzezinska@ukw.edu.pl; Tel.: +48-52-349-62-50
}

check for updates

Citation: Brzezińska, M.; Szatten, D. Babiński, Z. Prediction of

Erosion-Prone Areas in the Catchments of Big Lowland Rivers: Implementation of Maximum Entropy Modelling-Using the Example of the Lower Vistula River (Poland). Remote Sens. 2021, 13, 4775. https://doi.org/10.3390/rs13234775

Academic Editors: Donato Amitrano and Luca Cicala

Received: 27 October 2021

Accepted: 21 November 2021

Published: 25 November 2021

Publisher's Note: MDPI stays neutral with regard to jurisdictional claims in published maps and institutional affiliations.

Copyright: (c) 2021 by the authors. Licensee MDPI, Basel, Switzerland. This article is an open access article distributed under the terms and conditions of the Creative Commons Attribution (CC BY) license (https:// creativecommons.org/licenses/by/ $4.0 /)$.

\begin{abstract}
It is common knowledge that erosion depends on environmental factors modified by human activity. Erosion within a catchment area can be defined by local lithological, morphometric, hydrological features, etc., and land cover, with spatial distribution described by means of remote sensing tools. The study relied on spatial data for the catchment of the Lower Vistula-the biggest river in Poland. GIS (SAGA, QGIS) tools were used to designate the spatial distribution of independent environmental variables that determined the process of erosion according to land cover types within the Lower Vistula catchment (Corine Land Cover). In addition, soil loss in the catchment area was calculated using the USLE model (Universal Soil Loss Equation). The spatial data was used to determine the predictive power of variables for the process of erosion by applying the maximum entropy model (MaxEnt) commonly used in fields of science unrelated to fluvial hydrology. The results of the study pointed directly to environmental features strongly connected with the process of erosion, identifying areas susceptible to intensified erosion, and in addition positively verified by USLE. This testifies to the correct selection of the proposed method, which is a strong point of the presented study. The proposed interdisciplinary approach to predict erosion within the catchment area (MaxEnt), widely supported by GIS tools, will allow the identification of environmental pressures to support the decision-making process in erosion-prone areas.
\end{abstract}

Keywords: erosion prediction; maximum entropy model; USLE model; Vistula River

\section{Introduction}

Erosion is a natural process affecting the relief of the landscape. Land degradation is the main environmental problem intensified by climate change and anthropogenic activity [1]. The movement of weathered material from the surface by a relocating factor to another location is defined as soil erosion [2].

A catchment is a basic unit of ecosystem functioning [3], both in terms of cycles of matter and energy. Their balance in a catchment-being a spatial unit-allows the balancing of soil erosion. Irregular patterns of land use and vegetation diversity are determinants of hydrological responses of catchments [4]. Soil erosion results from transformations of the environment by natural and anthropogenic factors. Soil erosion and sediment yield are complex problems affected by various factors [5]. Soil erosion can be defined as a complex of mechanisms dependent on lithological, topographic, climatic, water, and vegetation conditions [6]. Soil erosion is a key driver of soil degradation [7]. Approximately $58 \%$ of soil degradation worldwide is a result of soil erosion [8]. The estimated annual cropland loss due to soil erosion is ca. 10 million ha, which contributes to a reduction in agricultural production $[9,10]$. Soil losses due to soil erosion are estimated at ca. 75 billion tonnes [11]. The long-term impact of soil erosion is significant [12], but human existence is also affected by its short-term impact [13], including floods, desertification, and damage 
to infrastructure-buildings, railways, roads, etc. Thus, meteorological and hydrological extremes have a significant impact on the process of erosion. Understanding the erosion process and modelling the amount of eroded material addresses sheet and rill erosion [14]. There are different types of erosion, such as gully and rill erosion, each affected by various conditioning factors [15]. Rivers and lakes are the receptacles of eroded soil, which often transport a sediment load of chemicals (e.g., pesticides). It poses a threat to the ecological status defined in the Framework Water Directive [16].

The Geographic Information System (GIS) and remote sensing (RS) tools enable monitoring land cover changes; thus, they are useful in the conservation of the environment. Field surveys, satellite photo interpretation, and remote sensing analyses can assess the presence or absence of soil erosion.

Soil erosion prediction models are classified into two groups: (i) empirical and (ii) physical process-based models. The first group includes: the Pacific Southwest Interagency Committee [17], Universal Soil Loss Equation (USLE) [18], and Revised Universal Soil Loss Equation (RUSLE) [19], etc. Their advantage is that they are universal and straightforward, but they do not allow the predicting of erosion as a set of physical phenomena [20]. Physical process-based models, including the European Soil Erosion Model (EUROSEM) [21], and Erosion Potential Method (EPM) [22], based on multiple parameters, can describe the physical mechanism of erosion in detail with a high degree of accuracy. The above-described methods analyze soil erosion by attempting to estimate the volumes or masses of soil loss. Generally, results for small catchments are of sufficient quality. The more parameters are taken into account, the more difficult is their use on a wide scale due to frequent deficiency of input data, calibration data, and high labor consumption [23].

Soil erosion modelling is a promising tool for the identification of erosion-prone areas, especially in cases of low data availability. Stochastic methods are commonly applied to model the response of a binary outcome (presence/absence) in relation to a set of independent geographical variables. The most often used methods include: Binary Logistic Regression (BLR) [24], Classification and Regression Trees (CART) [25], Maximum Entropy Model (MaxEnt) [26], and Stochastic Gradient Boosting (SGB) [27], and Analytical Hierarchy Process (AHP) model [28]. Stochastic approaches proved to be successful for water erosion susceptibility and landslide hazard assessment at the catchment scale. The assessment of MaxEnt modelling suitability shows that this is a user-friendly tool using a ROC (receiver operating characteristics) curve. The strong points of this method are its low cost and time-savings.

The study aimed to demonstrate the suitability of maximum entropy (MaxEnt) in determining the susceptibility of catchments to denudation using the example of the Lower Vistula catchment. To this end, a digital elevation model was used together with environmental data from national and European resources subject to field analyses using SAGA and QGIS software. The adopted objectives could be accomplished by comparing the outcomes of MaxEnt and USLE for the analyzed catchments. The study is important not only from the point of view of determining the degree of denudation in the catchment, but it also indicates a possibility of using interdisciplinary methods for long-term observation of environmental pressures.

\section{Materials and Methods}

\subsection{Study Area}

The study area is the Lower Vistula-one of the main tributaries of the Baltic Sea. Detailed studies were concentrated along a stretch of $391 \mathrm{~km}$ from the outlet of the Narew into the Vistula $(550+500 \mathrm{~km})$ to the outlet of the Vistula into the Gulf of Gdańsk $\left(941+300 \mathrm{~km}\right.$ ) (Figure 1). The study area is $34,260.16 \mathrm{~km}^{2}$ situated between latitudes $54^{\circ} 21^{\prime} 32.68^{\prime \prime} \mathrm{N}$ and $51^{\circ} 37^{\prime} 56.42^{\prime \prime} \mathrm{N}$ and longitudes $17^{\circ} 00^{\prime} 13.32^{\prime \prime} \mathrm{E}$ and $21^{\circ} 00^{\prime} 34.40^{\prime \prime} \mathrm{E}$. 
(a)

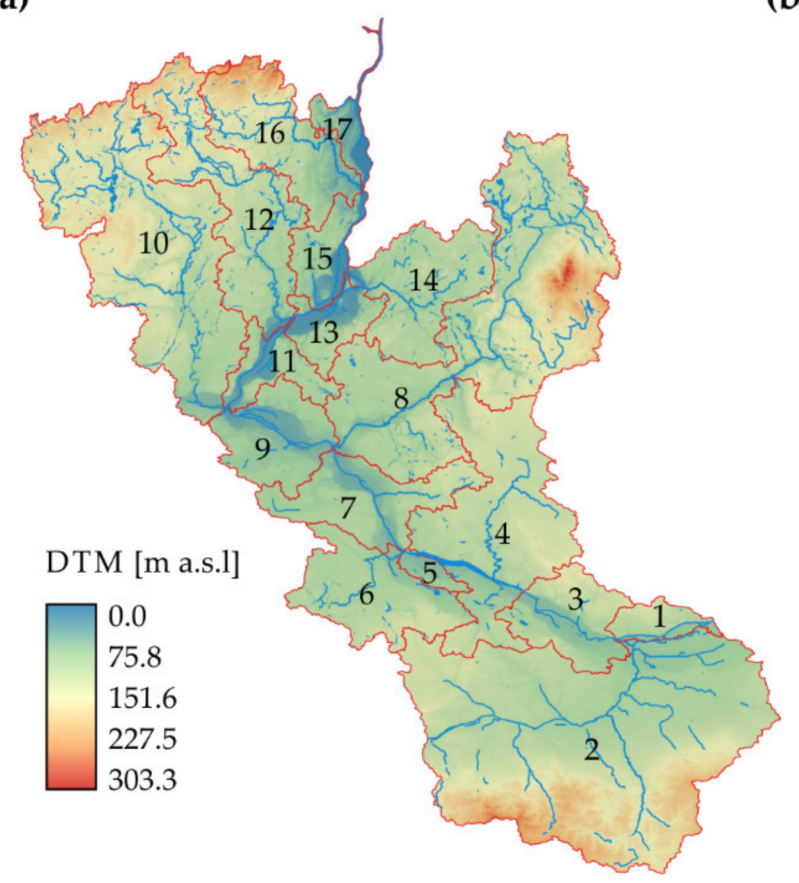

(b)

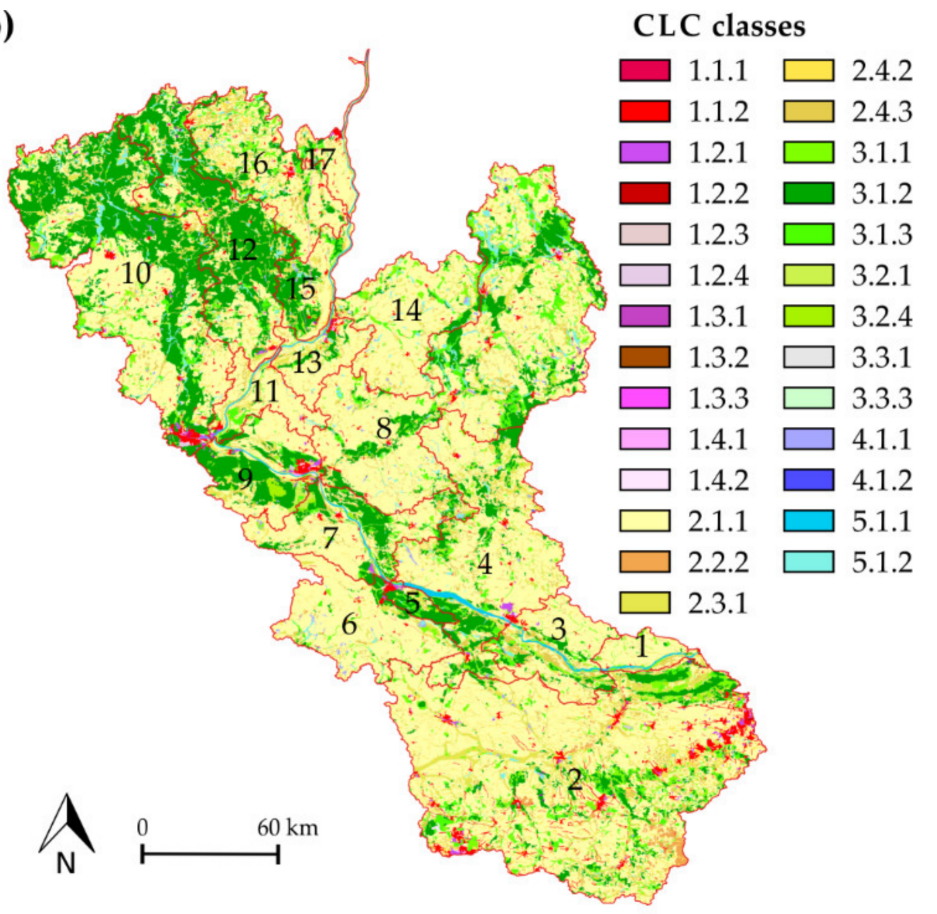

Figure 1. Study area: (a) the sub-catchment in the DEM, and (b) land cover [29]. Legend: CLC classes after Heymann et al. [30] Table A1; catchments numbered as per Table 1.

Table 1. Characteristics of the analyzed sub-catchments.

\begin{tabular}{|c|c|c|c|c|}
\hline No & Name of Sub-Catchment & $\begin{array}{c}\text { Area } \\
\left(1000 \mathrm{~km}^{2}\right)\end{array}$ & $\begin{array}{c}\text { Height } \\
\text { Difference } \\
\text { (m) }\end{array}$ & $\begin{array}{c}\text { River } \\
\text { Network } \\
\text { Density } \\
\left(\mathbf{k m} / \mathbf{k m}^{2}\right)\end{array}$ \\
\hline 1 & Vistula from Narew R. to Bzura R. & 0.38 & 96.6 & 1.00 \\
\hline 2 & Bzura River & 7.74 & 212.7 & 1.37 \\
\hline 3 & Vistula from Bzura R. to Włocławek Reservoir & 1.07 & 106.0 & 1.43 \\
\hline 4 & Włocławek Reservoir & 3.02 & 104.1 & 1.52 \\
\hline 5 & $\begin{array}{l}\text { Vistula from dam (Włocławek R.) to } \\
\text { Zgłowiączka R. }\end{array}$ & 0.18 & 89.9 & 0.98 \\
\hline 6 & Zgłowiączka River & 1.52 & 96.0 & 1.45 \\
\hline 7 & Vistula from Zgłowiączka R. to Drwęca R. & 1.40 & 106.0 & 1.28 \\
\hline 8 & Drwęca River & 5.36 & 272.9 & 1.07 \\
\hline 9 & Vistula from Drwęca R. to Brda R. & 1.16 & 77.0 & 1.22 \\
\hline 10 & Brda River & 4.67 & 190.8 & 0.93 \\
\hline 11 & Vistula from Brda R. to Wda R. & 0.63 & 88.8 & 1.31 \\
\hline 12 & Wda River & 2.33 & 287.7 & 0.98 \\
\hline 13 & Vistula from Wda R. to Osa R. & 0.60 & 108.7 & 1.26 \\
\hline 14 & Osa River & 1.61 & 127.5 & 1.15 \\
\hline 15 & Vistula from Osa R. to Wierzyca R. & 0.63 & 112.8 & 1.63 \\
\hline 16 & Wierzyca R. & 1.61 & 277.7 & 1.05 \\
\hline 17 & Vistula from Wierzyca R. to estuary & 0.37 & 110.2 & 1.42 \\
\hline
\end{tabular}


The study area extends over two glaciation stadials: North Polish and Middle Polish [31] (Figure 1). Catchments situated in the north are part of the Poznan phase and Pomeranian phase, while those in the south and east-are part of the Middle Polish glaciation stage and the Leszno phase. This is reflected by relief and landforms-lowlands and depressions formed by the accumulative or erosive activity of rivers such as, for example, physico-geographical units named by Kondracki [31]: Lower Vistula Valley (314.8), Torun-Eberswalde Ice Marginal Valley (315.3), and Central Masovia Lowland (318.7). The southern edges of the study area are old glacial heights (Southern Masovia Hills-318.8), and the northern part is mainly young glacial heights with outwash plains-including Southern Pomerania Lakeland (314.6-7) and Iława Lakeland (314.9). This description is reflected in formations building these units. Older areas are built of till, sand, and periglacial cover with gravel outliers of moraines and kames from older glaciation periods, intersected by river valleys and basin-like depressions. Lakeless denudation plains dominate the landscape. However, the young glacial landscape in the north shows multiple landlocked depressions and lakes associated with glacier ice vanishing. Hilly moraine heights (Krajna Heights) are intersected by outwash plains (e.g., the Brda and the Gwda). Marginal forms of respective phases of glaciation and heights partitioned by latitudinal stretches of ice-marginal valleys of main rivers (the Noteć, the Warta) and longitudinal gorge sections of rivers (the Brda, the Drawa) have a characteristic trellis pattern.

Figure 1 shows the 17 sub-catchments. The Lower Vistula is a hydrographic axis of the analyzed area in which 10 immediate catchments were delineated. In addition, seven main second-order tributaries were identified: the Bzura, the Zgłowiaczka, the Drweca, the Brda, the Wda, the Osa, and the Wierzyca. All were analyzed in detail, as presented in Table 1.

Considering riverbed transformation due to anthropogenic activity as a criterion, Babiński [32] distinguished four main sections of the Lower Vistula: (i) an unregulated braiding section upstream of the Włocławek Reservoir, (ii) the Włocławek Reservoir, (iii) a section downstream of the dam up to the outlet of the Tazzyna river at the stage of regulation, and (iv) a section downstream of the outlet of the Tażyna regulated in the late 19th century.

The examined catchments are situated within reach of climate regions [33]—enumerated subsequently from the outlet of the Vistula to the south: IV-Lower Vistula region characterized by weather types without precipitation; VIII-East Pomeranian region with weather types featuring lower temperatures and precipitation; IX-Chełmno-Torun region with predominantly warm weather without precipitation; $X$-West Masurian region with more precipitation days; XV-Central Greater Poland region with warm weather without precipitation; XVII-Central Polish region featuring frequent precipitation; and XVIII-Central Masovian region with predominantly warm and very warm weather without precipitation.

The study area features quite an even spatial distribution of the annual sum of atmospheric precipitation amounting to $530 \mathrm{~mm}$ in its southern part, and in the Vistula Valley, these values are lower and increase to $580 \mathrm{~mm}$ northwards.

\subsection{Materials}

Spatial Data

The source materials were: (i) commonly available numerical data from the National Geodetic Resource-comprising data for the territory of Poland; (ii) data from the Copernicus Land Monitoring Service (CLMS) - a database of spatial information for the European Union; (iii) meteorological data of the Institute of Meteorology and Water ManagementNational Research Institute acting as the State Hydrological and Meteorological Service.

Digital Map of the Hydrographic Division of Poland (MPHP). MPHP provides information about the boundaries of catchments and geometric and descriptive characteristics of the river network. It is a hydrographic database in SHP format in the Polish metric system of coordinates (PUWG 1992-EPSG 2180), covering the whole of Poland and a part of the catchments of the Vistula and the Oder outside the state boundaries. The hydrological data in MPHP are valid for the year 2007. 
Digital Elevation Model (DEM). The base for spatial analyses was a digital elevation model with $1 \mathrm{~m} \times 1 \mathrm{~m}$ spatial resolution deriving from the Head Office of Geodesy and Cartography resources in Poland. Data was used in ASCII XYZ GRID file format in PUWG 1992 reference system. DEM is a digital model of a fragment of the Earth's surface built of a set of points for presenting terrain relief in XYZ dimensions [34,35].

Corine Land Cover Database. The COoRdination and INformation on the Environment programme (CORINE Land Cover-CLC) is an initiative of the European Commonwealth implemented in 1985. The database contains information about land cover, specified at 3 levels of generality. According to technical assumptions, CLC uses a Minimum Mapping Unit of 25 ha for area phenomena and a minimum width of $100 \mathrm{~m}$ for linear phenomena [30]. The database used was valid for land cover in 2006, where 27 out of 44 land cover forms were distinguished [36]. A shapefile was transformed into a raster $30 \times 30 \mathrm{~m}$ spatial resolution using the "shapes to grid" tool in the SAGA software.

Atmospheric precipitation sum. The spatial distribution of the annual atmospheric precipitation sum was determined using data from the Institute of Meteorology and Water Management-National Research Institute based on automated 24-h observations at 54 firstorder weather stations in Poland. Based on the interpolation tool (SAGA software) the raster data in $30 \mathrm{~m} \times 30 \mathrm{~m}$ spatial resolution of precipitation sum from 1951 to 2010 was created.

\subsection{Methods}

\subsubsection{Spatial Analyses}

QuantumGIS software (version 3.4.12) was used to identify seventeen sub-catchments from the MPHP database, which provided the basis for further analyses. Using a geoprocessing tool (Clip), DEM and CLC were clipped to match the study area. The System for Automated Geoscientific Analyses-SAGA software (version 2.3.2) [37] was used to transform - generalize DEM to a horizontal resolution of $30 \times 30 \mathrm{~m}$, taking into account (i) the large surface of the study area and (ii) to eliminate noise resulting from the excessively detailed source material. Tool: Mosaicking with B-spline interpolation was used. The geoprocessing tools specified in Table 2. were used to determine 10 spatial parameters. At the last stage, all spatial layers were transformed into a uniform ASCII GRID format. The selection of independent variables that often affect model predictive efficiency is a significant step for preparing the analyses [38].

Table 2. Description of parameters and related sources. Group of parameters: H-hydrological, T-topographical.

\begin{tabular}{ccccc}
\hline No & Parameter & Code & Group & \multicolumn{2}{c}{ References } \\
\hline 1 & Channel Network Base Level & CNBL & H & {$[37]$} \\
\hline 2 & Convergence Index & CI & T & {$[39]$} \\
\hline 3 & Cross-sectional Curvature & CSC & T & {$[40]$} \\
\hline 4 & Flow Accumulation & FA & H & {$[41]$} \\
\hline 5 & Longitudinal Curvature & LC & T & {$[40]$} \\
\hline 6 & LS-Factor & LSF & T & {$[42]$} \\
\hline 7 & Melton Ruggedness Number & MRN & T & {$[43]$} \\
\hline 8 & Slope & SLP & T & {$[44]$} \\
\hline 9 & Stream Power Index & SPI & H & {$[42]$} \\
\hline 10 & Topographic Wetness Index & TWI & T & {$[45]$} \\
\hline
\end{tabular}




\subsubsection{Maximum Entropy Model}

The spatial distribution of the probability of the 10 analyzed indicators for 27 identified land cover types in 17 sub-catchments susceptible to denudation was examined using maximum entropy [46,47].

The distribution being computed is the one that has maximum entropy among those satisfying the constraints that the expectation of each feature matches its empirical average. This distribution can be proved to be identical with the Gibbs distribution that maximizes the product of the probabilities of sample locations, where a Gibbs distribution takes the form:

$$
P(x)=\exp \left(c_{1} \times f_{1}(x)+c_{2} \times f_{2}(x)+c_{3} \times f_{3}(x) \ldots\right) / Z
$$

where $c_{1}, c_{2}, \ldots$ are constants, $f_{1}, f_{2}, \ldots$ are the features, and $Z$ is a scaling constant that ensures that $P$ sums to 1 over all grid cells. The algorithm that is implemented by this program is guaranteed to converge to values of $c_{1}, c_{2}, \ldots$, which give the (unique) optimum distribution $P$.

MaxEnt software v. 3.4.0. was used. Maximum entropy based on the presenceonly algorithm is a popular tool for habitat suitability predicting and environmental modelling [48]. It was also successfully used in geoarchaeological research [49] and biometeorological studies [50], groundwater potential mapping [51], and landslide susceptibility mapping [52], which testifies to its versatility. A strong point of MaxEnt modelling is the fast examination of a large study area. A weak point of the proposed method is its dependency on the accessibility of source data and adequate quality reflected in the modelling results.

A dependent variable was 17 sub-catchments with 25,000 random presence/absence background points identified for each with QuantumGIS software. Phillips and Dudik [47] proved that 10,000 background points are sufficient to prepare a good model. The pseudoabsence sample in our study was 2.5 times bigger to ensure the correct correlation of results. The independent variable for each of the 17 sub-catchments was 10 indicators forming a spatial matrix saved as an ASCII file, describing different morphological and hydrological aspects. The model was subjected to random validation two times: a training sample of the presence data ( $80 \%$ of data) and a test sample of the presence data ( $20 \%$ of data). The process takes into account sample variability and representativeness during validation.

Modelling results were expressed as a percentage share of respective independent variables in the model, with ROC (receiver operating characteristics) / AUC (area under curve) values determining the predictive efficiency of the model. ROC is a well-recognized index used successfully in spatial modelling, e.g., Chen et al. [53]. The AUC curve shows the true positive rate (sensitivity) over a false positive rate (1-specificity) for all possible locations. The closer the AUC value to 1, the higher the predictive execution of the model. The shapes of prediction curves represent the type of correlation between specificity (X-axis), derived from the training area, and sensitivity (Y-axis), as a spatial distribution of erosion landforms in the test area. The further the trend from the diagonal is, the better the predictive value of the model, whereas the steeper the lower part of the curve is, the greater its predictive capability [54]. According to the criterion proposed by Hosmer and Lemeshow [55], $0.6<$ AUC $<0.8$ values testify to the acceptable association of the model, $0.8<$ AUC $<0.9$ values-excellent association, and AUC $>0.9$ means outstanding prediction.

\subsubsection{USLE Soil Erosion Model}

The quality of MaxEnt modelling was verified using the Universal Soil Loss Equation (USLE), as proposed by Wischmeier and Smith [18], successfully universally applied [1,56-59] to determine soil loss in the catchment area.

$$
A=R \times K \times L S \times C \times P,
$$

The model was used in a horizontal resolution of $30 \mathrm{~m} \times 30 \mathrm{~m}$ referring to MaxEnt. The input data was based on: (i) spatial distribution of the annual atmospheric precipita- 
tion sum-R factor; (ii) the Soil Erodibility High-Resolution dataset for Europe [60]$\mathrm{K}$ factor; (iii) calculation of the slope-length factor using SAGA software [42] based on DEM-LS factor; (iv) soil erosion cover-management factor based on Corine Land Cover type [29] proposed by Panagos et al. [61] —C factor; and (v) support practice factor based on a different slope gradient, proposed by Panagos at al. [62] - P factor. Soil loss (in $\mathrm{t} \mathrm{ha}^{-1}$ year $^{-1}$ ) was computed with SAGA software using Grid-Calculator.

To determine the qualitative correlation between AUC and USLE (A) modelling results and 10 independent variables, the r.covar tool (QuantumGIS v.3.4.12. with GRASS) was used to obtain the correlation matrix of rasters, which supports the validity of MaxEnt in determining the susceptibility of catchments to denudation using the example of the Lower Vistula catchment.

\section{Results}

\subsection{Hydrological and Topographic Features of the Lower Vistula}

The spatial distribution of values of the 10 analyzed indicators shows certain mutual similarities determined by geomorphic features of respective catchments (Table 3). In order to precisely illustrate the spatial variability in the values of 10 independent variables of the model, analyses were carried out: (i) in catchments of the Vistula River-in the longitudinal profile and (ii) in sub-catchments of its main second-order tributaries.

Table 3. Characteristics of independent variables in the analyzed catchments of the Lower Vistula. Key: A-in catchments of the Vistula, B - in catchments of the main second-order tributaries of the Vistula, C-in respective catchments-the catchment number is shown in brackets, as per Table 1 .

\begin{tabular}{|c|c|c|c|c|c|c|c|c|c|c|}
\hline \multirow{2}{*}{\multicolumn{2}{|c|}{ No Parameter }} & \multicolumn{2}{|c|}{ Av } & \multicolumn{2}{|c|}{ PCTL50 } & \multicolumn{2}{|c|}{ PCTL90 } & \multirow[t]{2}{*}{ Min } & \multirow{2}{*}{$\begin{array}{c}\text { Max } \\
C\end{array}$} & \multirow[t]{2}{*}{ Av } \\
\hline & & A & B & A & B & A & B & & & \\
\hline 1 & CHBL & 0.013 & 0.020 & 0.000 & 0.000 & 20.508 & 20.430 & $0(17)-63(1.2)$ & $\begin{array}{c}106.079 \\
(9)-309.943(8) \\
\end{array}$ & $\begin{array}{c}37.818 \\
(17)-130.404(10) \\
\end{array}$ \\
\hline 2 & $\mathrm{CI}$ & 86.929 & 121.111 & 88.853 & 113.058 & 125.816 & 170.550 & $-100(1-17)$ & $100(1-17)$ & $\begin{array}{c}-0.100 \\
(17)-0.054(2)\end{array}$ \\
\hline 3 & CSC & 0.00004 & 0.00005 & 0.000 & 0.000 & 0.0007 & 0.0009 & $\begin{array}{c}-0.044 \\
(14)--0.009(6)\end{array}$ & $\begin{array}{c}0.012(12)-0.026 \\
(14)\end{array}$ & $\begin{array}{c}0.00001 \\
(2)-0.00009 \text { (5) }\end{array}$ \\
\hline 4 & FA & 984463 & $\begin{array}{c}2268 \\
789\end{array}$ & 5932 & 5372 & $\begin{array}{l}188 \\
822 \\
\end{array}$ & $\begin{array}{l}152 \\
238 \\
\end{array}$ & $961(1-17)$ & $\begin{array}{c}40542680(5)-7 \\
459329024(2)\end{array}$ & $\begin{array}{c}161064(5)-3 \\
289950(10)\end{array}$ \\
\hline 5 & $\mathrm{LC}$ & -0.00004 & -0.00005 & 0.000 & 0.000 & 0.001 & 0.001 & $\begin{array}{c}-0.034 \\
(13)--0.012(2)\end{array}$ & $\begin{array}{c}0.011(2)-0.031 \\
(14)\end{array}$ & $\begin{array}{c}-0.0001 \\
(5)--0.00001(2)\end{array}$ \\
\hline 6 & LSF & 0.167 & 0.205 & 0.075 & 0.105 & 0.380 & 0.493 & $0(1-17)$ & $\begin{array}{c}4.178(2)-22.248 \\
(10)\end{array}$ & $\begin{array}{c}0.112(2)-0.325 \\
(16)\end{array}$ \\
\hline 7 & MRN & 0.114 & 0.134 & 0.054 & 0.073 & 0.282 & 0.353 & $0(1-17)$ & $\begin{array}{c}2.034(6)-4.949 \\
(15)\end{array}$ & $\begin{array}{c}0.086(4)-0.195 \\
(16)\end{array}$ \\
\hline 8 & SLP & 0.017 & 0.020 & 0.011 & 0.015 & 0.039 & 0.048 & $0(1-17)$ & $\begin{array}{c}0.256(2)-0.552 \\
(15)\end{array}$ & $\begin{array}{c}0.012(2)-0.031 \\
(16)\end{array}$ \\
\hline 9 & SPI & 196.224 & 479.492 & 0.896 & 1.203 & 10.857 & 13.312 & $0(1-17)$ & $\begin{array}{c}85282 \\
(5)-13814359(10)\end{array}$ & $\begin{array}{c}30.848 \\
(5)-1016.788(10)\end{array}$ \\
\hline 10 & TWI & 9.949 & 9.589 & 9.446 & 8.928 & 13.454 & 12.906 & $\begin{array}{c}3.917(15)-4.808 \\
(6)\end{array}$ & $\begin{array}{c}21.142(5)-26.206 \\
\text { (2) }\end{array}$ & $\begin{array}{c}8.907 \\
(16)-10.114(9)\end{array}$ \\
\hline
\end{tabular}

Depending on the location of the examined sub-catchment in the whole catchment area of the Lower Vistula, average CNBL values oscillated between 37.8 (the Vistula from the outlet of the Wierzyca to the outlet into the Gulf of Gdańsk, No. 17) and 130.4 (the Brda catchment, No. 10) (Table 3). A prominent lowland relief of all the examined catchments is reflected by the PCTL50 and PCT90 values of this indicator. The maximum values in the analyzed catchments occur in their most elevated parts (Figure 2). The average FA for 
main second-order tributaries of the Vistula distinctly higher than that for its immediate catchments (Table 3) is proof of a considerably expanded fluvial system of tributaries of the Lower Vistula. It is also corroborated by higher SPI values for catchments of the main second-order tributaries of the Vistula (Table 3). The highest values of FA and SPI assume spatial distribution corresponding to the river network layout in the analyzed catchments, with an increase in the indicator's values down the river. However, higher PCTL90 for FA and higher values of the TWI characteristics imply a higher water storage capacity of the bed of the main river - the Vistula.

Considering the spatial distribution of CI values, the examined catchments have strongly varied terrain relief (Figure 2), with reference to the DTM. There are some catchments with predominant concave forms (the Vistula from the outlet of the Wierzyca to its outlet into the Gulf of Gdańsk, No. 17) and catchments where convex forms dominate (Bzura, No. 2) (Table 3). Higher values of CI characteristics denote more varied terrain relief on the main second-order tributaries of the Vistula (Table 3). Spatial distribution of the maximum values of CSC and LC strongly refers to edge zones of river valleys (Figure 2). Again, higher values are characteristic for catchments of second-order tributaries of the Vistula (Table 3). A similar distribution can be observed for SLP values that reach the maximum in the edge zones. The maximum SLP values are 0.256 for the Bzura (No. 2) and 0.552 for the Vistula from the outlet of the Osa to the outlet of the Wierzyca (No. 16), respectively (Table 3). An equally linear course is characteristic for LSF. Its maximum values are characteristic of the Brda (No. 10), and they amount to 22.248 (Table 3). However, the PCTL90 for LSF implies a potentially higher supply of material from catchments of the main second-order tributaries of the Vistula than from immediate catchments of the Vistula (Table 3). The four indicators mentioned above have a linear distribution of maximum values in the examined catchments.

Indicators equally strongly associated with relief intensity are MRN and LSF. Depending on the location of the examined sub-catchment in the whole catchment area of the Lower Vistula, the average MRN oscillated between 0.086 (Włocławek Reservoir, No. 4) and 0.195 (Wierzyca, No. 16) (Table 3). Catchments of the main second-order tributaries of the Vistula featured higher PCTL50 and PCTL90 for this indicator. The indicator mentioned above has an island distribution reflecting the variety of landforms within the area of moraine heights (Figure 2).

\subsection{Determining the Predictive Power of Environmental Parameters in MaxEnt Modelling}

The validation achieved mainly excellent AUC values, and the results are in line with the overall model results. The average AUC test value is not significantly different from AUC training for both methods (Tables A2 and A3).

Depending on the CLC type, the percentage of the examined parameters assumed a unique distribution. However, in nearly all cases, two parameters-MRN and CNBLdominated in MaxEnt (Table 4). For anthropogenic areas (CLC 1.X), agricultural land (CLC 2.X), and forestland (CLC 3.X), these indicators were predominant in the model. The percentage ranged from $26.8 \%$ (CLC 2.3.1, catchment No. 6) to 81.4\% (CLC 2.1.1, No. 16) for MRN and from 31.4\% (CLC 2.3.1, No. 3) to 75.9\% (CLC 3.1.1, No. 17) for CNBL. It is worth noting that for CLC 2.1.1 in all catchments, the dominant parameter was MRN. Only for No. 13 in CLC 3.1.1, the SPI parameter was predominant. For wetlands and water bodies (CLC 4.X and 5.X), the predominant parameter was more varied. Apart from CNBL (from 23.2\%-CLC 5.1.2, No. 9 to 99.9\%-CLC 5.1.1, No. 2), SLP (from 31.3\%-CLC 4.1.1, No. 8 to $54.8 \%$-CLC 5.1.2, No. 8) and FA (from 22.0\%-CLC 4.1.1, No. 4 to $42.8 \%$-CLC 5.1.2, No. 17) had also a significant share. In addition, for CLC 5.1.1, the dominant parameter was CNBL in all the examined catchments. 

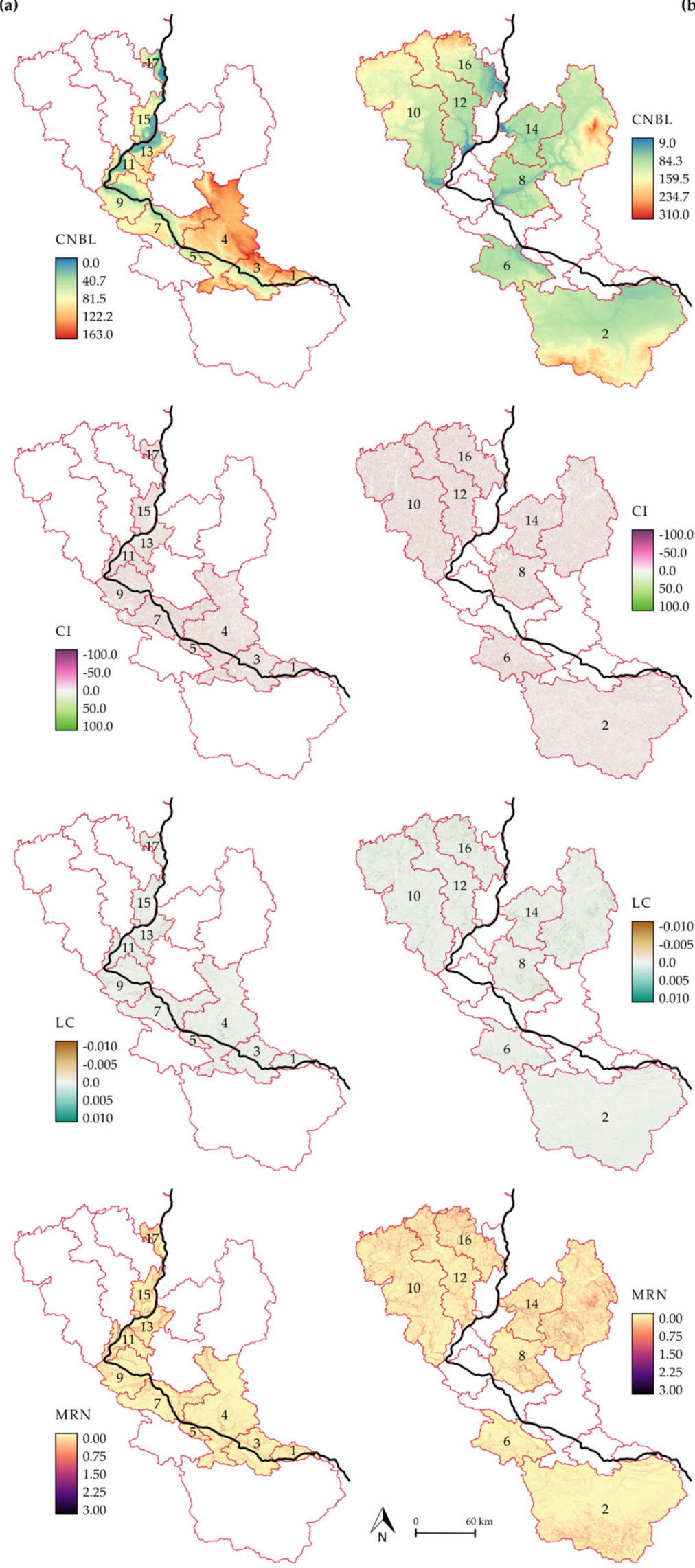

Figure 2. Spatial distribution of selected independent variables: CNBL, CI, LC, MRN in catchments of the Vistula (a) and its main second-order tributaries (b); catchments numbered as per Table 1. 
Table 4. Percentage of the dominant parameter in MaxEnt in the examined catchments for selected CLC types. Key: CNBL—blue, MRN—green, SPI—orange, FA—red, SLP—violet, LSF—gray; catchments numbered as per Table 1.

\begin{tabular}{|c|c|c|c|c|c|c|c|c|c|}
\hline & 1.1.2 & 2.1.1 & 2.3.1 & 2.4.3 & 3.1.1 & 3.1.2 & 4.1.1 & 5.1.1 & 5.1.2 \\
\hline \multicolumn{10}{|c|}{ The Catchments of the Longitudinal Profile of the Vistula River } \\
\hline 1 & 52.6 & 71.0 & 36.8 & 46.5 & 39.5 & 37.4 & - & 62.1 & 44.5 \\
\hline 3 & 41.4 & 72.8 & 31.4 & 49.9 & 39.4 & 45.6 & 37.2 & 36.0 & 37.4 \\
\hline 4 & 43.1 & 73.5 & 40.1 & 51.9 & 36.7 & 61.8 & 22.0 & 85.1 & 31.9 \\
\hline 5 & 51.0 & 57.0 & 46.5 & 40.1 & 34.1 & 68.9 & - & 92.4 & 25.5 \\
\hline 7 & 40.9 & 76.8 & 34.7 & 53.9 & 40.1 & 63.1 & 21.8 & 71.2 & 38.4 \\
\hline 9 & 45.3 & 67.4 & 31.3 & 41.5 & 49.9 & 67.9 & 33.6 & 56.2 & 23.2 \\
\hline 11 & 46.4 & 78.3 & 58.9 & 39.0 & 50.6 & 53.2 & 42.4 & 63.7 & 40.8 \\
\hline 13 & 44.3 & 74.3 & 64.2 & 40.8 & 25.8 & 42.7 & 47.2 & 66.3 & 54.8 \\
\hline 15 & 41.7 & 63.5 & 29.8 & 46.5 & 41.4 & 53.6 & 33.5 & 77.8 & 38.0 \\
\hline 17 & 35.0 & 74.2 & 47.5 & 41.2 & 75.9 & 37.6 & 38.2 & 66.0 & 42.8 \\
\hline \multicolumn{10}{|c|}{ The main second-order tributaries of the Vistula River } \\
\hline 2 & 45.5 & 67.3 & 33.2 & 41.1 & 40.1 & 45.4 & 24.8 & 99.9 & 40.0 \\
\hline 6 & 38.2 & 79.5 & 26.8 & 46.6 & 31.5 & 55.6 & 32.1 & - & 40.6 \\
\hline 8 & 51.5 & 79.7 & 37.8 & 55.6 & 49.6 & 68.9 & 31.3 & - & 50.8 \\
\hline 10 & 49.0 & 72.6 & 35.7 & 51.6 & 47.7 & 79.1 & 40.3 & 65.8 & 36.0 \\
\hline 12 & 44.0 & 65.7 & 33.8 & 47.9 & 40.0 & 80.6 & 36.9 & - & 39.4 \\
\hline 14 & 57.6 & 84.6 & 37.9 & 58.6 & 63.1 & 53.1 & 29.0 & - & 47.7 \\
\hline 16 & 47.6 & 81.4 & 33.9 & 63.4 & 55.1 & 75.3 & 42.7 & - & 66.0 \\
\hline
\end{tabular}

Apart from determining the predictive power of environmental features, MaxEnt outcomes showed areas susceptible to denudation.

Figure 3 presents a percentage of the surface area in respective AUC value ranges in the catchments of the longitudinal profile of the Vistula (A) and its main second-order tributaries (B). Regarding the Vistula catchments, on average, $0.9 \%$ of their surface area is a highly susceptible area (AUC > 0.8). MaxEnt showed that a sub-catchment having the largest total surface area with the best prediction is the Vistula catchment from the Brda to the Wda (No. 11), where AUC $>0.8$ accounts for $1.7 \%$ of the surface area $\left(10.34 \mathrm{~km}^{2}\right)$, while the catchment of the Włocławek Reservoir (No. 4) has only a $0.6 \%$ share of such an area $\left(18.96 \mathrm{~km}^{2}\right)$. For the main second-order tributaries of the Vistula, the total highly susceptible area (AUC > 0.8 ) is on average $0.7 \%$. The largest percentage share of this area $\left(0.9 \%-43.95 \mathrm{~km}^{2}\right)$ is characteristic of the Brda catchment (No. 10). On the other hand, the Wda catchment (No. 12) has the lowest share of an area with AUC $>0.8$ predictions accounting for approximately $0.6 \%\left(14.27 \mathrm{~km}^{2}\right)$.

(a)

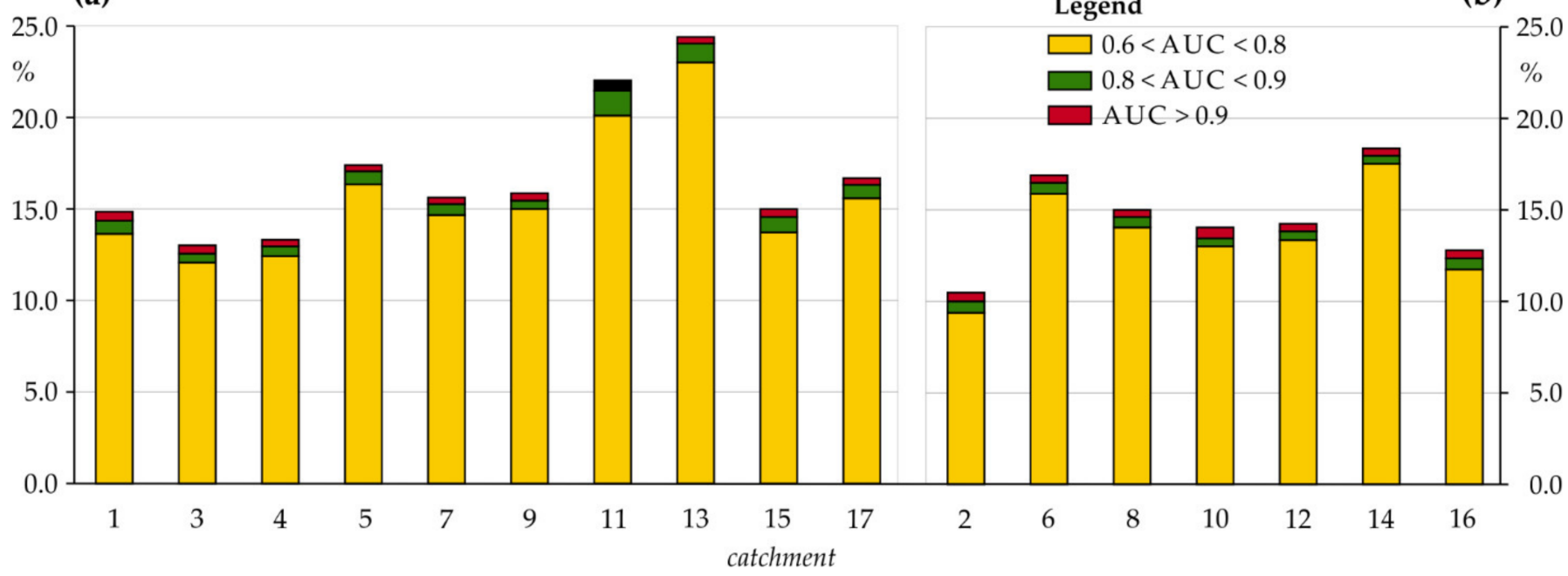

Figure 3. Percentage of the area in respective AUC ranges in catchments of the Vistula (a) and its main second-order tributaries (b); catchments numbered as per Table 1. 
A decidedly larger total surface area is occupied by land with an adequate predictive power $(0.6<$ AUC $<0.8)$, accounting for-on average- $15.7 \%$ in sub-catchments in the longitudinal profile of the Vistula and $13.6 \%$ in the catchments of the main second-order tributaries of the Vistula. In the first case-catchments of the Vistula-this area is from $12.1 \%$ in the catchment from the outlet of the Bzura to the Włocławek Reservoir (No. 3) to a maximum of $23.0 \%$ in the catchment area from the Wda to the Osa (No. 13). On the other hand, in the catchments of the main second-order tributaries of the Vistula, the percentage of this area oscillates between 9.4\% (Bzura, No. 2) and 17.5\% (Osa, No. 14).

MaxEnt showed the remaining area of the examined catchments as poorly susceptible (AUC < 0.6). On average, they account for $83.4 \%$ and $85.7 \%$ of the area, respectively, in sub-catchments in the longitudinal profile of the Vistula and catchments of the main second-order tributaries of the Vistula.

The areas identified by the model as having the largest predictive power for the course of denudation (AUC > 0.8) are zoned, which is connected with the presence of areas characterized by the most intense relief. For the Vistula catchments, these are mostly the Vistula River Valley edge zones-from the outlet of the Brda to the outlet of the Wda (No. 11)—or the edge zones of smaller watercourses in those catchments (Figure 4). In many cases, they are arranged as elongated courses of connected areas such as from the outlet of the Brda to the outlet to the Wda (No. 11) or from the outlet of the Osa to the outlet of the Wierzyca (No. 15). Another characteristic feature is the greater noticeability of such spatial arrangements alongside the longitudinal profile of the Vistula.

(a)

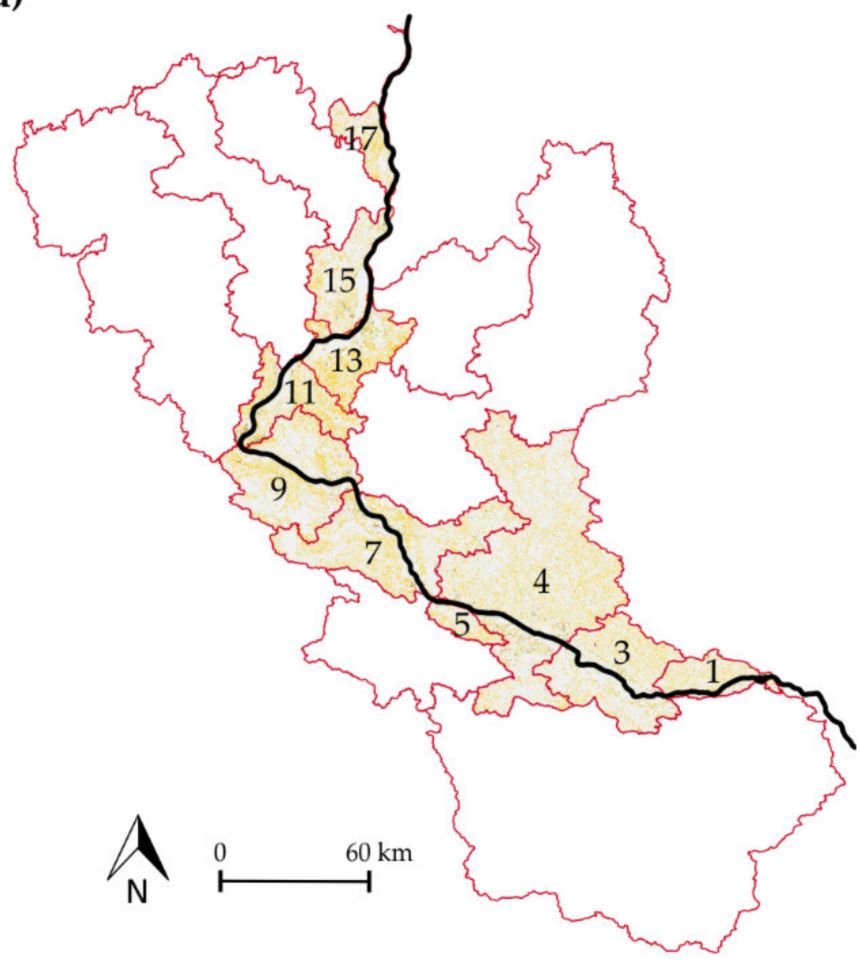

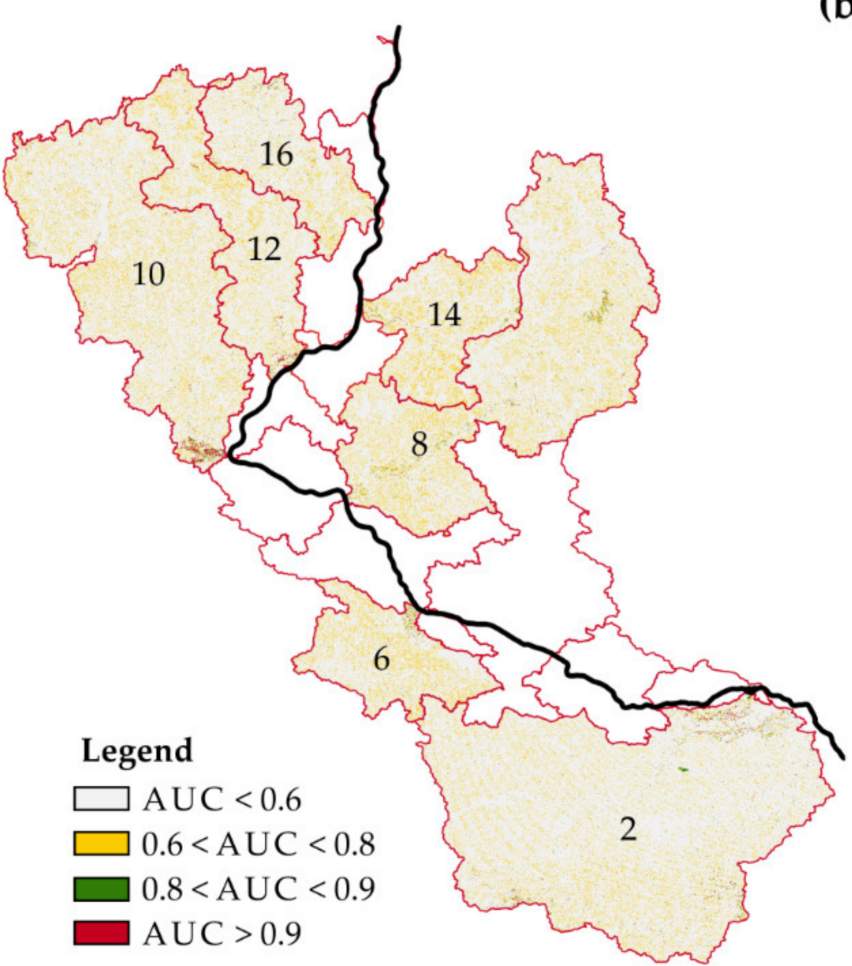

Figure 4. Spatial distribution of the predictive force of MaxEnt according to AUC value ranges in selected catchments of the Vistula (a) and its main second-order tributaries (b); catchments numbered as per Table 1.

For the main second-order tributaries of the Vistula, it can also be observed that areas with AUC $>0.8$ are associated with the edge zones of watercourses and other areas with significant differences in height. However, in this case, the area is decidedly less dense. Areas with strong predictive power are also clustered at the outlets of rivers, especially those transformed by hydrotechnical structures (Zgłowiaczka-No. 6, Brda-No. 10, and Wda-No. 12) (Figure 4). 
A qualitative correlation was found between MaxEnt outcomes (AUC value) and the intensity of relief for independent environmental variables: CI, CSC, LCURV, and MRN. Considering the number of correlated raster points in the catchments from 183817 to 8042837 , the correlation coefficient for the independent variables mentioned above was a maximum of 0.380 (Figure 5), which implies a correct selection of independent variables in the model.

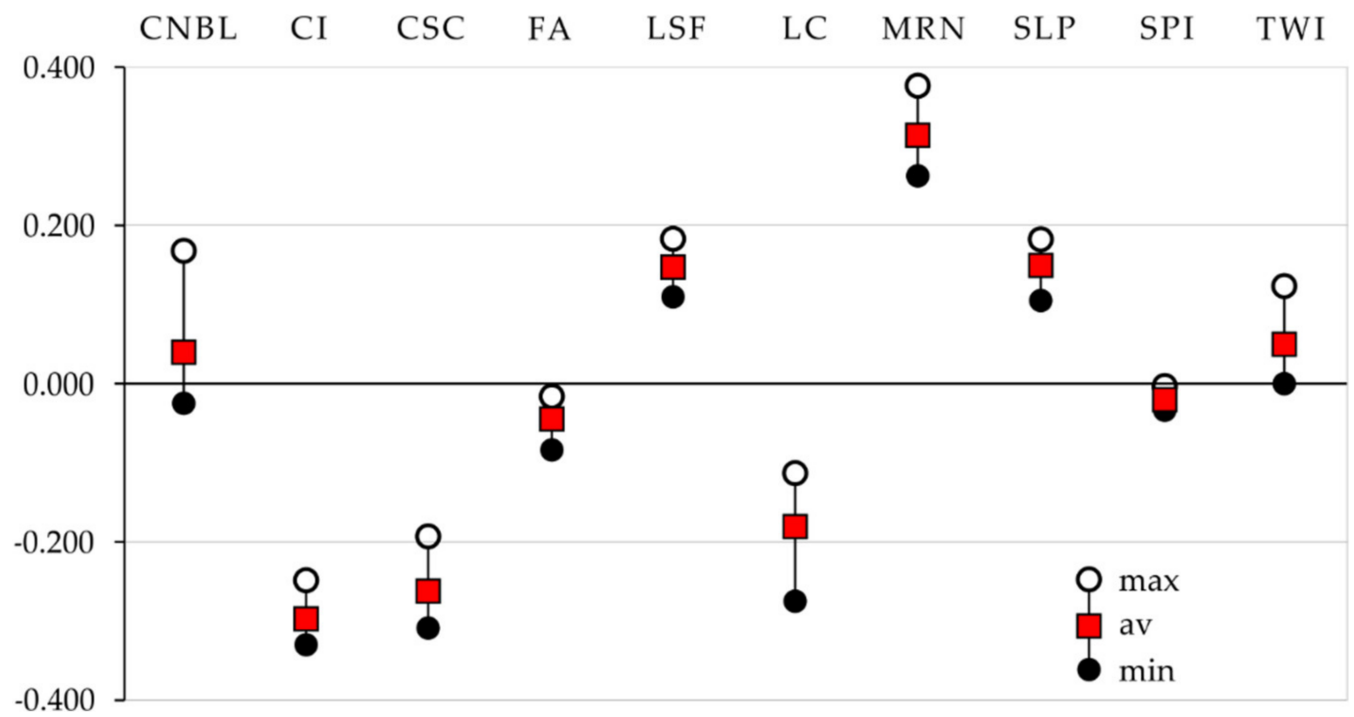

Figure 5. The correlation matrix of rasters between MaxEnt outcomes (AUC) and independent variables for the examined catchments of the Lower Vistula.

\subsection{Soil Loss Predict (USLE) in the Lower Vistula Catchments}

The total soil loss $\left(\mathrm{A}\right.$, in $\mathrm{t} \mathrm{ha}^{-1}$ year $\left.^{-1}\right)$ in the analyzed catchments of the Lower Vistula is relatively insignificant. Catchments of the main second-order tributaries of the Vistula have a higher average A value than immediate catchments of this river. These values are $1.122 \mathrm{t} \mathrm{ha}^{-1}$ year $^{-1}$ and $1.193 \mathrm{t} \mathrm{ha}^{-1}$ year $^{-1}$, respectively. Average values range from $0.074 \mathrm{tha}^{-1}$ year $^{-1}$ (the Vistula from the dam in Włocławek to the outlet of the Zgłowiaczka, No. 5) to $2.070 \mathrm{t} \mathrm{ha}^{-1}$ year ${ }^{-1}$ (the Vistula from the outlet of the Wda to the outlet of the Osa, No. 13) (Figure 6).

(a)

(b)

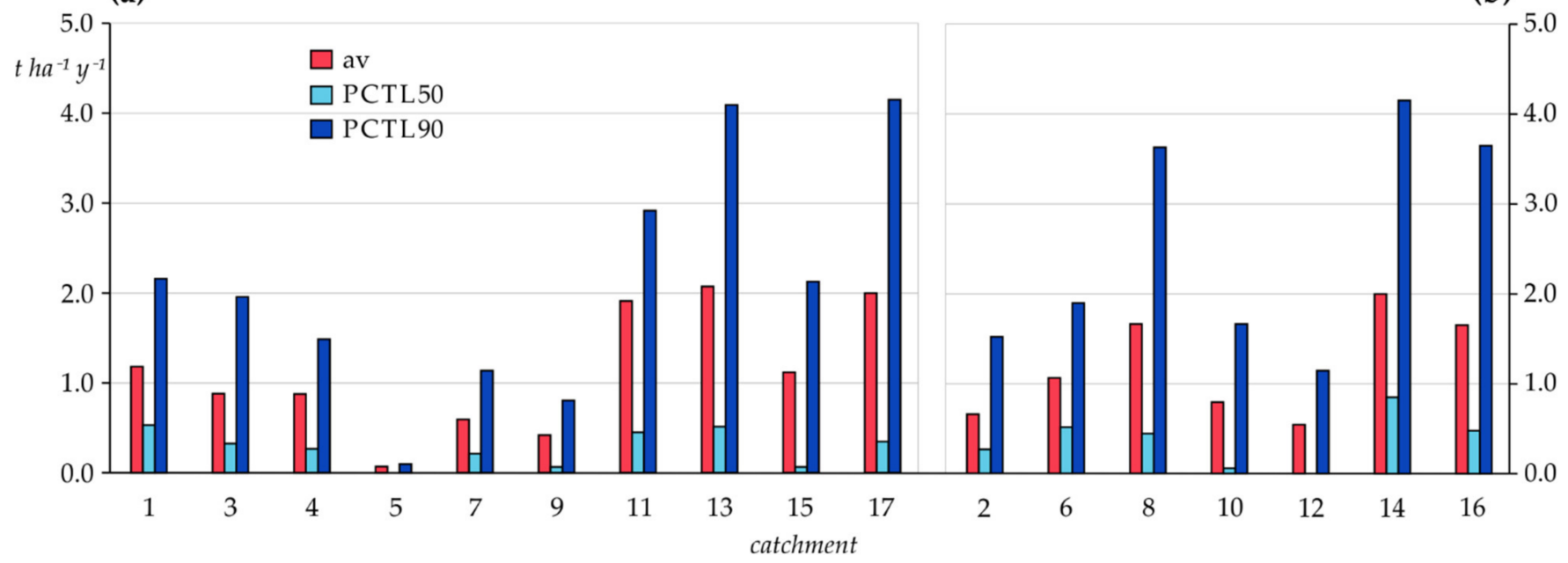

Figure 6. Soil loss according to USLE in the catchments of the Vistula (a) and its main second-order tributaries (b) Legend: red-mean value; light blue_-PCTL50; dark blue-PCTL90; catchment numbered as per Table 1. 
Strong zonality and a relatively small surface area of land with the highest A value in all the examined catchments are illustrated by 50 (PCTL50) and 90 percentile (PCTL90) (Figure 6). The mean value of A for all the examined catchments is higher than PCTL50, which testifies to a decidedly lower soil loss in a predominant area. PCTL50 accounts for a maximum of $48.4 \%$ of the mean value of $\mathrm{A}$. The occurrence of small areas with a strong soil loss potential is additionally depicted by a PCTL90 value considerably exceeding the mean value of A (Figure 6). This relationship also occurs in all the examined catchments, whereas PCTL90 accounts for a maximum of $236.1 \%$ of the mean value of A.

The impact of a relatively small surface area with intense terrain relief in all the analyzed catchments, illustrated by PCTL50 and PCTL90 values, can also be noticed in the spatial distribution of A (Figure 7). The highest A values in the Vistula catchments are arranged as elongated courses of interconnected areas-with spatial connections to valleys of rivers (including the Vistula, the Drwęca, the Osa, the Bzura) and edges of moraine heights (including Starogród Lakeland, Świecie Upland, Krajna Lakeland, Chełmno-Dobrzyń Lakeland, and Płońsk-Ciechanów Heights) (Figure 7A).

(a)

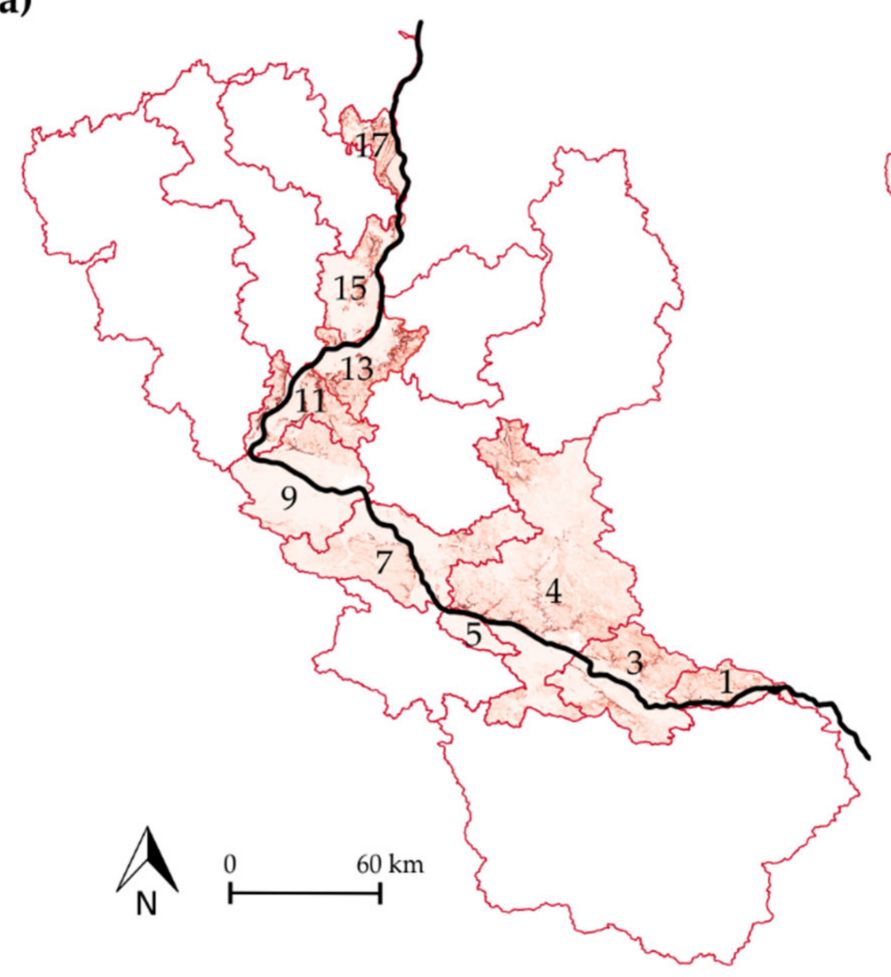

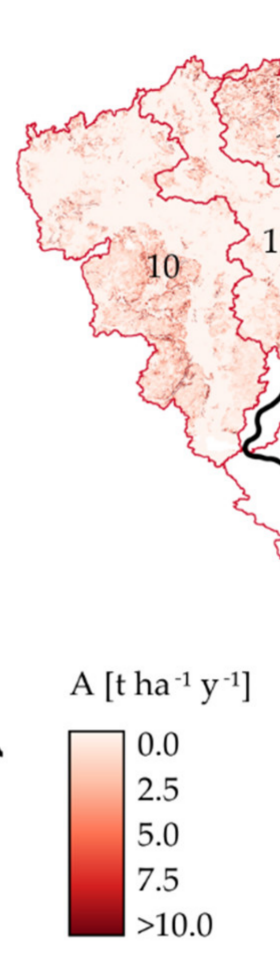

(b)

Figure 7. Spatial distribution of soil loss as predicted by USLE in the catchments of the Vistula (a) and its main second-order tributaries (b); catchments numbered as per Table 1 .

For the main second-order tributaries of the Vistula, the highest A values occur in old glacial heights (Łódź Hills, Rawa Heights, and Inowrocław Plain) and young glacial heights (Chełmno Lakeland, Iława Lakeland, Krajna Lakeland, and Cassubian Lakeland) (Figure 7B).

A significant spatial link was observed between mean soil loss (A) and the predictive power of MaxEnt for areas with AUC > 0.6 in 17 examined catchments (Figure 8). The qualitative distribution reflects the areas with the maximum denudation value for both analyzed methods. 
AUC
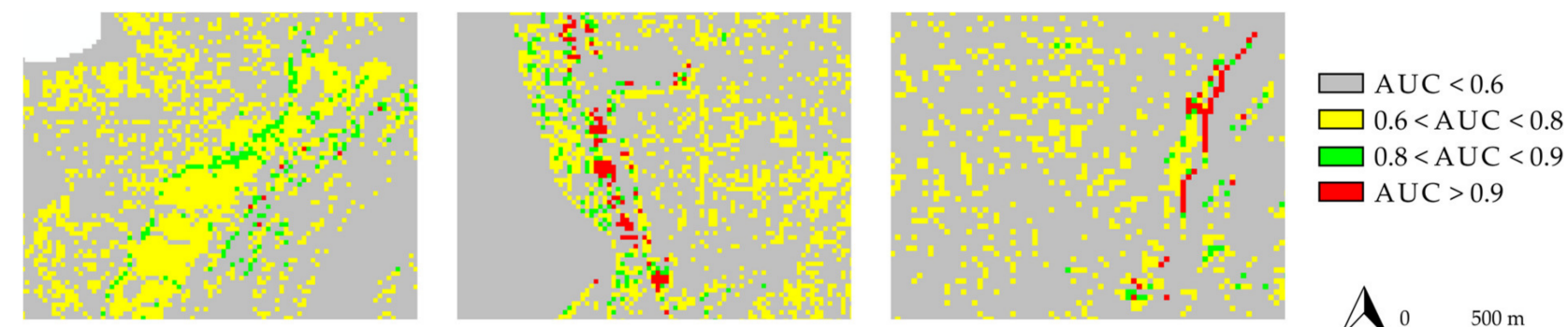

A
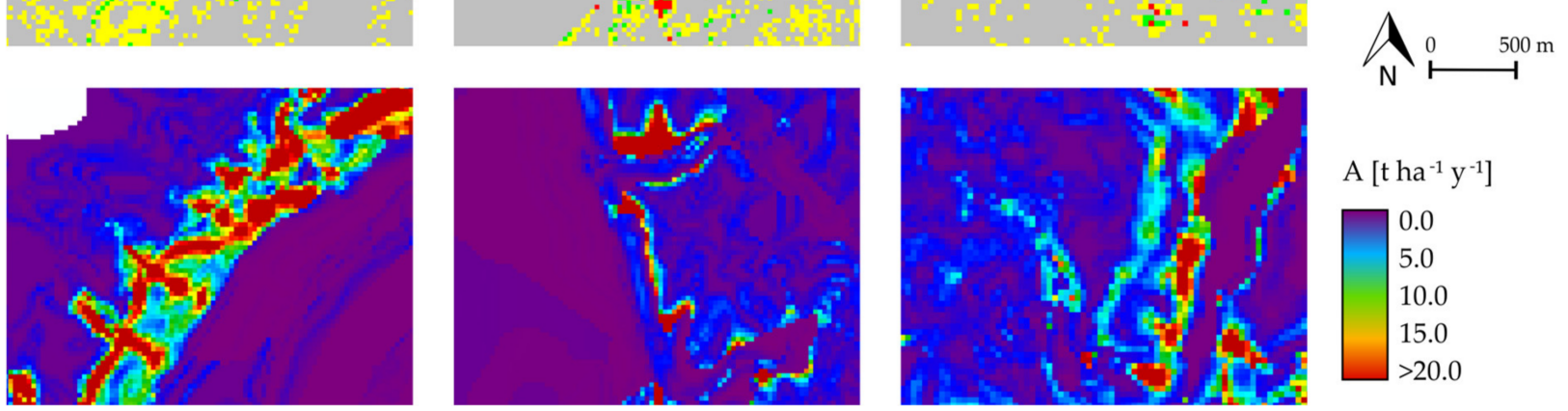

Figure 8. The spatial relationship between the predictive power of the MaxEnt model (AUC) and mean soil loss (A) for selected areas on the examined catchment.

\section{Discussion}

The process of erosion in terms of the fluvial system is limited by both environmental factors [6] and human activity. It leads to the transformation of environmental components, that is, modification of terrain relief; but not only that, it also affects the usability of environmental components for humans-usually negatively-as the surface area of land affected by this process increases, e.g., erosion of roads and crop fields. The course of erosion is strongly dependent on latitudinal and longitudinal geomorphic zones and differs between warm and cold areas and dry and humid areas [63]. However, even in a relatively uniform study area-in the catchment of the Lower Vistula-lithological, topographic, climatic, hydrological, and vegetation features are highly complex.

The impact of lithological features of the study area is manifested both in independent environmental variables and MaxEnt outcomes and in USLE prediction. It delimits a clear division into young glacial catchments (in the north of the study area) and old glacial catchments (in the south). The surface area of denudation plains connected with older phases of Pleistocene glaciation [31] is to a lesser extent potentially prone to soil erosion than the areas of young glacial heights with river valleys having intense orography.

Apart from lithology, reflected directly by $\mathrm{K}$ factor in USLE model and indirectly related with TWI in MaxEnt model, erosion-prone areas are determined by the intensity of terrain relief. Studies by Saha et al. [64] lead to similar conclusions, where soil erosion results in a combination of several variables, and relief has the most substantial relationship with susceptibility to soil erosion in the catchment. Due to the lowland nature of all the examined catchments, reflected in relatively low CNBL values (Table 3), the supply of sediments into the fluvial system due to erosion is relatively limited. The maximum values of this indicator concurrently identify the sources of the potential supply of sediments-being the upstream parts of the examined catchments. Analyses of independent variables in subcatchments in the longitudinal profile of the Lower Vistula, using SAGA software, showed that CNBL decreases (Table 3), which is connected with the decreasing absolute value of the erosion base. It is highly significant for the Lower Vistula catchments as intensive denudation in the lowest sub-catchments is nearly excluded. The significance of the erosion base indicator for gully erosion was mentioned in the study by Arabameri et al. [65], where using maximum entropy modelling, a high percentage of height above nearest drainage (HAND) was observed. On the other hand, a gradual increase in the values of indicators such as: CI, CSC, LSF, MRN, and SLP (Table 3) implies intensified significance of relief for denudation. Perhaps this is associated with the young glacial relief mentioned above in 
some of the examined catchments. The potential sources of sediments are mainly the edge zones of river valleys, as illustrated by CSC, LC, and SLP (Figure 2). Conoscenti et al. [66] pointed out that land surfaces affected by diffuse water erosion are mainly associated with slopes having positive CSC values and a limited upslope contributing area (as illustrated by LSF and SPI). Concurrently, in the study by Cama et al. [67], gully erosion was controlled, among other indicators, by SLP. However, badlands and sheet erosion were under the influence of CNBL and SLP. In the longitudinal profile of the Lower Vistula, a decrease in LC was noted, which implies an increase in the percentage of concave landforms, at the same time being temporary or ultimate receptacles of erosion sediments. There can be numerous landlocked depressions formed by dead ice in the study area.

Hydrological conditions in the catchment are equally important from the point of view of erosion. In terms of the fluvial system, the Lower Vistula can be described as a big lowland river affected by a single dam in Włocławek [32], supplied by considerably smaller rivers and streams-also those transformed by hydrotechnical structures $[68,69]$. Rivers are not only an erosion factor but they also transport sediments. Hydrological transformations in the catchment of the Lower Vistula are reflected in the hydrological regime of rivers creating the catchment-indirectly affecting water erosion and the sediment transport continuum [70,71]. Analyses of independent variables showed that SPI in the longitudinal profile of the Lower Vistula tends to decrease except in catchment No. 4, where the Włocławek Reservoir is located. It illustrates the impact of the presence of a large dam on the water regime within a catchment transformed by hydrotechnical structures. Concurrently, a decrease in TWI in the longitudinal profile of the Lower Vistula implies a reduction in the percentage of land susceptible to the retention of water in the river channel. It illustrates hydrotechnical changes (structures in the river channel and on the flood plain) since the 19th century [72]. Conforti et al. [73] prepared a gully erosion susceptibility model where significant indicators were, e.g., SPI, SLP, TWI, and LSF. Considering differences in erosion types: gully and rill erosion, Pournader et al. [74] used the Jackknife test in MaxEnt to generate a rill erosion susceptibility map, and the results showed a high contribution of SLP and SPI factors in the model. The average FA value for the main second-order tributaries of the Vistula higher than that for its immediate catchments (Table 3) testifies that they have a more developed fluvial system. This results in: (i) increased susceptibility to water erosion-linear in the upstream, headwater part of the catchment, and (ii) higher number of streams capable of supplying material from the catchment area. Such a developed fluvial system generates high retention capacity of the watercourse-here, the Vistula — being the ultimate receptacle for all watercourses in the fluvial system of the Lower Vistula. This fact is reflected by higher PCTL90 for FA and higher values of the TWI characteristics of the Vistula catchments in the longitudinal profile (Table 3).

MaxEnt outcomes showed that MRN and CNBL were dominant indicators (Table 4). This primarily referred to artificial surfaces (CLC 1.X), agricultural areas (CLC 2.X), and forests (CLC 3.X). Studies by Zabihi et al. [75] using MaxEnt pointed out that elevation and land use are the main factors determining gully erosion. These two factors are reflected in, for instance, SLP and TWI, which were significant for the presented model. The maximum values of another significant indicator-MRN-have an island distribution referring to areas with varied relief in the examined heights (Figure 2). On the other hand, the indicator dominant in MaxEnt changed for wetlands and water bodies (CLC 4 and 5). Apart from MRN, the most significant parameter in some catchments was SLP or FA-the potential concentrated run-off (Table 4).

Denudation is, to a large extent, limited by land cover. In most of the analyzed subcatchments, agricultural areas were dominant-usually type 2.1.1 (non-irrigated arable land) accounting for $22 \%$ of the surface area in catchment No. 12 (Wda), where the dominant land cover was forest; up to $75.43 \%$ in No. 6 (Zgłowiączka). Respective sub-catchments featured varied artificial surfaces; the share of the dominant type 1.1.2 (discontinuous urban fabric) ranged from $0.67 \%$ in No. 14 (Osa) to $5.01 \%$ in No. 5 (the Vistula from the dam to 
the Zgłowiączka). Most of the sub-catchments were quite highly afforested. The share of green areas ranged from $9 \%$ in No. 1 (the Vistula from the Narew to the Bzura) to $70 \%$ in No. 5 (the Vistula from the dam to the Zgłowiaczka).

The total surface area of the most erosion-prone land (AUC $>0.8$ ) is insignificant in MaxEnt (Figure 3). This is mainly due to the lowland nature of the examined catchments. On the other hand, areas with good predictive power (AUC > 0.6) in MaxEnt have a significant share of $23.0 \%$ maximum in the catchment from the Wda to the Osa (Figure 3). This is directly linked with the vertical relief of the catchment-determining the sources of sediments - and with the density of the river network connected with hydrological conditions - contributing to transportation of the eroded material.

Total soil loss (A) determined by USLE modelling in the examined catchments of the Lower Vistula is relatively small and amounts to a maximum of $2.070 \mathrm{t} \mathrm{ha}^{-1}$ year $^{-1}$ (the Vistula from the outlet of the Wda to the outlet of the Osa, No. 13) (Figure 6). The mean value of $\mathrm{A}$ for all the examined catchments is higher than PCTL50 for A, which testifies to a decidedly lower soil loss in a predominant area (Figure 2) and corroborates the statement about the lowland nature of the Lower Vistula catchment. The research by El Jazouli et al. [57] used the USLE model and showed that strongly degraded land was located in the upstream part of the catchment, while conversely, the weakly degraded land was situated in the downstream part of the catchment. In addition, in the Vistula catchments, the maximum A values are distributed as elongated courses of interconnected areas-with spatial connections to valleys of rivers-whereas, for the main second-order tributaries of the Vistula, their distribution corresponds to the distribution of old glacial and young glacial heights.

Study results show that the maximum entropy approach is helpful in research for determining the spatial distribution of the predictive power of environmental features in terms of possible denudation. The demonstrated spatial relationship between the AUC and A modelling outcomes (Figure 8) proves to be of sufficient quality for the used approach. The used modelling tools based on geospatial data can be applied in macroscale-in the study area of the Lower Vistula, and in the future in microscale-to analyze parts of catchments.

\section{Conclusions}

Based on the results of conducted studies on the suitability of remote sensing techniques and maximum entropy model on the erosion processes using the example of the Lower Vistula catchment, the following conclusions were drawn:

1. The Maximum Entropy Method (MaxEnt) was shown to be helpful in determining the predictive force of environmental features in terms of the course of erosion. The three-step validation of results: (i) auto-correlation of independent environmental variables; (ii) internal validation of MaxEnt; and (iii) correlation with the outcomes of USLE, shows that the used tools and spatial data are suitable for modelling erosionprone areas.

2. The results of studies allowed: (i) predicting quality-the total surface area of the analyzed catchment using MaxEnt within AUC value range, identical with the degree of susceptibility to erosion, and (ii) determining quantities-soil loss in the catchment area using USLE.

3. The total surface area of land highly prone to erosion (AUC $>0.8$ ) as indicated by MaxEnt is about $1 \%$ in each of the examined catchments, while in areas with sufficient predictive power $(0.6<$ AUC $<0.8)$, it exceeds $10 \%$. Total soil loss (A) in the analyzed catchments of the Lower Vistula is relatively small—on average amounting to about $1.1 \mathrm{t} \mathrm{ha}^{-1}$ year $^{-1}$, which implies that the intensity of erosion in the catchment of the Lower Vistula is relatively small. The spatial distribution of MaxEnt and USLE outcomes shows that areas being potential sources of sediments in the Lower Vistula catchment are the edge zones of river valleys and areas with intense terrain relief in the upstream parts of the examined sub-catchments. 
4. It was demonstrated that factors determining erosion in the catchment area are CNBL and MRN, reflecting hydrological and morphometric features of the catchment. The results of the study showed the presence of water as an energy carrier and height difference contribute to erosion. In addition, the study also noted the significance of land cover/use in the catchment area, which decidedly limits the power of independent environmental variables to predict erosion-pointing to a higher significance of FA or SLP.

5. The results of successful research using interdisciplinary methods, i.e., combining re-mote sensing techniques and maximum entropy modelling-used for determining the predictive power of the characteristics of plant and animal habitats-imply a need to look for new research methods helping to identify environmental pressures and supporting decision-making processes in erosion-prone areas.

Author Contributions: Conceptualization, M.B. and D.S.; methodology, D.S. and M.B.; software, M.B. and D.S.; validation, D.S. and Z.B.; formal analysis, investigation, M.B. and D.S.; resources, M.B.; data curation, M.B.; writing-original draft preparation, D.S. and M.B.; writing-review and editing, Z.B. and D.S.; visualization, M.B.; supervision, Z.B.; project administration, D.S.; funding acquisition, M.B., D.S., and Z.B. All authors have read and agreed to the published version of the manuscript.

Funding: This research and APC was funded by the Project Supporting Maintenance of Research Potential of the Institute of Geography at Kazimierz Wielki University [grant number BS/2016/N2].

Institutional Review Board Statement: Not applicable.

Informed Consent Statement: Not applicable.

Data Availability Statement: Publicly available datasets were analyzed in this study. This data can be found here: (i) hydrological data [https:/ / wody.isok.gov.pl/imap_kzgw/ accessed on 20 November 2021]; (ii) Digital Elevation Model data [https:/ / mapy.geoportal.gov.pl accessed on 20 November 2021]; (iii) Corine Land Cover Database [https:/ / land.copernicus.eu/pan-european/corine-landcover accessed on 20 November 2021]; (iv) climatic data [https:/ / danepubliczne.imgw.pl/ accessed on 20 November 2021].

Conflicts of Interest: The funders had no role in the design of the study; in the collection, analyses, or interpretation of data; in the writing of the manuscript, or in the decision to publish the results.

\section{Appendix A}

Table A1. Clases of Corine Land Cover (CLC) identified on study area.

\begin{tabular}{|c|c|c|}
\hline Level 1 & Level 2 & Level 3 \\
\hline \multirow{7}{*}{ 1. Artificial surfaces } & \multirow{3}{*}{$\begin{array}{l}\text { 1.2 Industrial, commercial and } \\
\text { transport units }\end{array}$} & $\begin{array}{l}\text { 1.1.1 Continuous urban fabric } \\
\text { 1.1.2 Discontinuous urban fabric }\end{array}$ \\
\hline & & 1.2.1 Industrial or commercial units \\
\hline & & $\begin{array}{l}\text { 1.2.2 Road and rail networks and } \\
\text { associated land } \\
\text { 1.2.3 Port areas } \\
\text { 1.2.4 Airports }\end{array}$ \\
\hline & \multirow[t]{2}{*}{$\begin{array}{l}\text { 1.3 Mine, dump and } \\
\text { construction sites }\end{array}$} & 1.3.1 Mineral extraction sites \\
\hline & & $\begin{array}{l}\text { 1.3.2 Dump sites } \\
\text { 1.3.3 Construction sites }\end{array}$ \\
\hline & \multirow[t]{2}{*}{$\begin{array}{l}\text { 1.4 Artificial, non-agricultural } \\
\text { vegetated areas }\end{array}$} & 1.4.1 Green urban areas \\
\hline & & 1.4.2 Sport and leisure facilities \\
\hline
\end{tabular}


Table A1. Cont.

\begin{tabular}{|c|c|c|}
\hline Level 1 & Level 2 & Level 3 \\
\hline \multirow{5}{*}{ 2. Agricultural areas } & 2.1 Arable land & 2.1.1 Non-irrigated arable land \\
\hline & 2.2 Permanent crops & 2.2.2 Fruit trees and berry plantations \\
\hline & 2.3 Pastures & 2.3.1 Pastures \\
\hline & $\begin{array}{l}\text { 2.4 Heterogeneous } \\
\text { agricultural areas }\end{array}$ & 2.4.2 Complex cultivation patterns \\
\hline & & $\begin{array}{l}\text { 2.4.3 Land principally occupied by } \\
\text { agriculture, with significant areas of } \\
\text { natural vegetation }\end{array}$ \\
\hline \multirow{5}{*}{$\begin{array}{l}\text { 3. Forest and semi } \\
\text { natural areas }\end{array}$} & 3.1 Forests & $\begin{array}{l}\text { 3.1.1 Broad-leaved forest } \\
\text { 3.1.2 Coniferous forest } \\
\text { 3.1.3 Mixed forest }\end{array}$ \\
\hline & $\begin{array}{c}3.2 \text { Scrub and/or herbaceous } \\
\text { vegetation associations }\end{array}$ & 3.2.1 Natural grasslands \\
\hline & & 3.2.4 Transitional woodland-shrub \\
\hline & $\begin{array}{c}\text { 3.3 Open spaces with little or } \\
\text { no vegetation }\end{array}$ & 3.3.1 Beaches, dunes, sands \\
\hline & & 3.3.3 Sparsely vegetated areas \\
\hline 4. Wetlands & 4.1 Inland wetlands & $\begin{array}{l}\text { 4.1.1 Inland marshes } \\
\text { 4.1.2 Peat bogs }\end{array}$ \\
\hline 5. Water bodies & 5.1 Inland waters & $\begin{array}{l}\text { 5.1.1 Water courses } \\
\text { 5.1.2 Water bodies }\end{array}$ \\
\hline
\end{tabular}

Table A2. Validated ranges of AUC values for CLC types in the catchments of the Vistula using cross-validation (C) and bootstrapping (B) methods; catchments numbered as per Table 1.

\begin{tabular}{|c|c|c|c|c|}
\hline \multirow{2}{*}{ CLC Type } & \multicolumn{2}{|c|}{ Cross-Validation } & \multicolumn{2}{|c|}{ Bootstrap } \\
\hline & Training & Test & Training & Test \\
\hline 1.1 .1 & $0.975(13)-0.996(9)$ & $0.974(13)-0.995(9)$ & 0.979 (13)-0.997 (9) & $0.975(13)-0.996(9)$ \\
\hline 1.1 .2 & $0.916(15)-0.949$ (1) & $0.913(15)-0.948(1)$ & $0.921(15)-0.937$ (1) & $0.920(15)-0.935(1)$ \\
\hline 1.2 .1 & $0.830(1)-0.981(17)$ & $0.826(1)-0.983(17)$ & $0.831(1)-0.975(17)$ & $0.832(1)-0.973$ (17) \\
\hline 1.2 .2 & $0.849(4)-0.996$ (17) & $0.846(4)-0.995(17)$ & $0.853(4)-0.997$ (17) & $0.851(4)-0.998$ (17) \\
\hline 1.2 .3 & $0.995(4)$ & $0.994(4)$ & $0.990(4)$ & $0.987(4)$ \\
\hline 1.2.4 & $0.500(1)-0.990(9)$ & $0.501(1)-0.988(9)$ & $0.505(1)-0.986(9)$ & $0.510(1)-0.984(9)$ \\
\hline 1.3 .1 & $0.745(4)-0.998(1)$ & $0.743(4)-0.997(1)$ & $0.754(4)-0.997(1)$ & $0.752(4)-0.996(1)$ \\
\hline 1.3 .2 & - & - & - & - \\
\hline 1.3 .3 & $0.931(15)-0.968(17)$ & $0.930(15)-0.966(17)$ & 0.935 (15)-0.972 (17) & $0.936(15)-0.971(17)$ \\
\hline 1.4 .1 & $0.726(7)-0.997(11)$ & $0.726(7)-0.998(11)$ & $0.720(7)-0.996(11)$ & $0.722(7)-0.997(11)$ \\
\hline 1.4 .2 & 0.977 (17)-0.997 (11) & $0.975(17)-0.998(11)$ & $0.970(17)-0.998(11)$ & $0.968(17)-0.996(11)$ \\
\hline 2.1 .1 & $0.643(13)-0.903(5)$ & $0.641(13)-0.902(5)$ & $0.635(13)-0.900(5)$ & $0.634(13)-0.896(5)$ \\
\hline 2.2 .2 & $0.915(4)-0.997(11)$ & $0.916(4)-0.996(11)$ & $0.910(4)-0.996(11)$ & $0.914(4)-0.992(11)$ \\
\hline 2.3.1 & $0.878(1)-0.951(3)$ & $0.879(1)-0.950$ (3) & $0.882(1)-0.960$ (3) & $0.883(1)-0.962$ (3) \\
\hline 2.4 .2 & $0.835(13)-0.958$ (5) & $0.836(13)-0.956(5)$ & 0.840 (13)-0.955 (5) & $0.836(13)-0.952(5)$ \\
\hline 2.4 .3 & $0.831(3)-0.944(5)$ & $0.830(3)-0.944(5)$ & $0.830(3)-0.945(5)$ & $0.828(3)-0.944(5)$ \\
\hline
\end{tabular}


Table A2. Cont.

\begin{tabular}{|c|c|c|c|c|}
\hline \multirow{2}{*}{ CLC Type } & \multicolumn{2}{|c|}{ Cross-Validation } & \multicolumn{2}{|c|}{ Bootstrap } \\
\hline & Training & Test & Training & Test \\
\hline 3.1 .1 & $0.873(1)-0.993(17)$ & 0.875 (1)-0.994 (17) & 0.865 (1)-0.989 (17) & 0.865 (1)-0.987 (17) \\
\hline 3.1 .2 & $0.662(5)-0.913(1)$ & $0.661(5)-0.910(1)$ & $0.674(5)-0.918(1)$ & $0.675(5)-0.917(1)$ \\
\hline 3.1 .3 & 0.877 (11)-0.948 (1) & $0.874(11)-0.944(1)$ & $0.878(11)-0.952(1)$ & $0.876(11)-0.950(1)$ \\
\hline 3.2 .1 & $0.923(9)-0.995$ (15) & $0.922(9)-0.993(15)$ & $0.930(9)-0.990(15)$ & $0.931(9)-0.987$ (15) \\
\hline 3.2 .4 & $0.910(9)-0.997(1)$ & $0.911(9)-0.996(1)$ & $0.912(9)-0.995(1)$ & $0.911(9)-0.991(1)$ \\
\hline 3.3 .1 & 0.985 (9)-0.999 (17) & $0.986(9)-0.998$ (17) & $0.988(9)-0.999(17)$ & 0.985 (9)-0.995 (17) \\
\hline 3.3 .3 & $0.985(9)-0.998$ (17) & 0.985 (9)-0.995 (17) & $0.980(9)-0.996(17)$ & $0.978(9)-0.993(17)$ \\
\hline 4.1 .1 & $0.976(15)-0.998(3)$ & $0.973(15)-0.995(3)$ & 0.965 (15)-0.995 (3) & $0.963(15)-0.996(3)$ \\
\hline 4.1 .2 & $0.772(4)$ & $0.770(4)$ & $0.768(4)$ & $0.765(4)$ \\
\hline 5.1 .1 & $0.926(1)-0.983(5)$ & $0.927(1)-0.982(5)$ & $0.927(1)-0.991(5)$ & $0.928(1)-0.992(5)$ \\
\hline 5.1 .2 & 0.960 (13)-0.996 (1) & $0.961(13)-0.994(1)$ & $0.962(13)-0.990(1)$ & $0.962(13)-0.991(1)$ \\
\hline
\end{tabular}

Table A3. Validated ranges of AUC values for CLC types in main second-order tributaries of Vistula using cross-validation (C) and bootstrapping (B) methods; catchments numbered as per Table 1.

\begin{tabular}{|c|c|c|c|c|}
\hline \multirow{2}{*}{ CLC Type } & \multicolumn{2}{|c|}{ Cross-Validation } & \multicolumn{2}{|c|}{ Bootstrap } \\
\hline & Training & Test & Training & Test \\
\hline 1.1 .1 & $0.791(16)-0.998(10)$ & $0.787(16)-0.996(10)$ & $0.790(16)-0.995$ (10) & $0.788(16)-0.994(10)$ \\
\hline 1.1 .2 & $0.888(2)-0.932(6)$ & $0.887(2)-0.930(6)$ & $0.880(2)-0.930(6)$ & $0.881(2)-0.927(6)$ \\
\hline 1.2 .1 & $0.933(2)-0.981(6)$ & $0.934(2)-0.980(6)$ & $0.935(2)-0.984(6)$ & $0.934(2)-0.980(6)$ \\
\hline 1.2 .2 & $0.794(10)-0.989(2)$ & $0.792(10)-0.990$ (2) & $0.799(10)-0.981(2)$ & $0.797(10)-0.983(2)$ \\
\hline 1.2 .3 & - & - & - & - \\
\hline 1.2 .4 & $0.867(2)-0.992(10)$ & $0.865(2)-0.990(10)$ & $0.863(2)-0.991(10)$ & $0.865(2)-0.990(10)$ \\
\hline 1.3 .1 & $0.769(2)-0.987(10)$ & $0.767(2)-0.988(10)$ & $0.769(2)-0.988(10)$ & $0.768(2)-0.985(10)$ \\
\hline 1.3 .2 & $0.993(12)$ & $0.992(12)$ & $0.991(12)$ & $0.986(12)$ \\
\hline 1.3 .3 & $0.921(2)-0.970(12)$ & $0.923(2)-0.968(12)$ & $0.920(2)-0.967(12)$ & $0.917(2)-0.965$ (12) \\
\hline 1.4 .1 & $0.781(16)-0.995(10)$ & $0.782(16)-0.996(10)$ & $0.780(16)-0.994(10)$ & 0.779 (16)-0.995 (10) \\
\hline 1.4 .2 & $0.944(2)-0.998(12)$ & $0.945(2)-0.996(12)$ & $0.945(2)-0.997(12)$ & $0.943(2)-0.996(12)$ \\
\hline 2.1 .1 & $0.633(14)-0.754(12)$ & $0.632(14)-0.750$ (12) & $0.642(14)-0.761$ (12) & $0.640(14)-0.761$ (12) \\
\hline 2.2 .2 & $0.500(10)-0.983(14)$ & $0.501(10)-0.980$ (14) & $0.502(10)-0.979$ (14) & $0.504(10)-0.976(14)$ \\
\hline 2.3 .1 & $0.977(2)-0.915(6)$ & $0.975(2)-0.917(6)$ & $0.976(2)-0.912(6)$ & $0.975(2)-0.913(6)$ \\
\hline 2.4 .2 & $0.821(16)-0.914(6)$ & $0.820(16)-0.912(6)$ & $0.827(16)-0.924(6)$ & $0.826(16)-0.924(6)$ \\
\hline 2.4 .3 & $0.819(16)-0.898(6)$ & $0.821(16)-0.894(6)$ & $0.827(16)-0.899(6)$ & $0.825(16)-0.898(6)$ \\
\hline 3.1 .1 & $0.870(14)-0.917(12)$ & $0.871(14)-0.915$ (12) & $0.875(14)-0.912(12)$ & $0.876(14)-0.910$ (12) \\
\hline 3.1 .2 & $0.657(12)-0.900(6)$ & $0.655(12)-0.900(6)$ & $0.655(12)-0.895(6)$ & $0.653(12)-0.891(6)$ \\
\hline 3.1 .3 & $0.846(16)-0.900(6)$ & $0.844(16)-0.901$ (6) & $0.845(16)-0.901(6)$ & $0.844(16)-0.900(6)$ \\
\hline 3.2 .1 & - & - & - & - \\
\hline 3.2 .4 & $0.878(12)-0.979(14)$ & $0.875(12)-0.978(14)$ & $0.877(12)-0.989(14)$ & $0.873(12)-0.988$ (14) \\
\hline 3.3 .1 & - & - & - & - \\
\hline 3.3 .3 & - & - & - & - \\
\hline
\end{tabular}


Table A3. Cont.

\begin{tabular}{cccccc}
\hline \multirow{2}{*}{ CLC Type } & \multicolumn{2}{c}{ Cross-Validation } & \multicolumn{2}{c}{ Bootstrap } \\
\cline { 2 - 5 } & Training & Test & Training & Test \\
\hline 4.1 .1 & $0.952(8)-0.986(12)$ & $0.951(8)-0.987(12)$ & $0.950(8)-0.983(12)$ & $0.950(8)-0.980(12)$ \\
\hline 4.1 .2 & $0.901(12)-0.997(10)$ & $0.900(12)-0.995(10)$ & $0.896(12)-0.992(10)$ & $0.895(12)-0.994(10)$ \\
\hline 5.1 .1 & $0.500(8)-0.999(10)$ & $0.505(8)-0.995(10)$ & $0.506(8)-0.996(10)$ & $0.507(8)-0.995(10)$ \\
\hline 5.1 .2 & $0.949(8)-0.981(6)$ & $0.952(8)-0.984(6)$ & $0.952(8)-0.994(6)$ & $0.950(8)-0.992(6)$ \\
\hline
\end{tabular}

\section{References}

1. Mihi, A.; Tarai, N.; Chenchouni, H. Can palm date plantations and oasification be used as a proxy to fight sustainably against desertification and sand encroachment in hot drylands? Ecol. Indic. 2019, 105, 365-375. [CrossRef]

2. Parlak, M. Determination of erosion risk according to CORINE methodology (a case study: Kurtboğazı Dam). Int. Congr. River Basin Manag. 2007, 1, 856.

3. Chen, S.; Zha, X. Evaluation of soil erosion vulnerability in the Zhuxi watershed, Fujian Province, China. Nat. Hazards J. Int. Soc. Prev. Mitig. Nat. Hazards 2016, 82, 1589-1607. [CrossRef]

4. Siriwardena, L.; Finlayson, B.L.; McMahon, T.A. The impact of land use change on catchment hydrology in large catchment: The Comet River, Central Queensland, Australia. J. Hydrol. 2006, 326, 199-214. [CrossRef]

5. Choubin, B.; Darabi, H.; Rahmati, O.; Sajedi-Hosseini, F.; Kløve, B. River suspended sediment modelling using the CART model: A comparative study of machine learning techniques. Sci. Total Environ. 2018, 615, 272-281. [CrossRef]

6. Guerra, A.J.T.; Fullen, M.A.; Jorge, M.D.C.O.; Bezerra, J.F.R.; Shokr, M.S. Slope processes, mass movement and soil erosion: A review. Pedosphere 2017, 27, 27-41. [CrossRef]

7. Wei, W.; Chen, L.; Fu, B.; Huang, Z.; Wu, D.; Gui, L. The effect of land uses and rainfall regimes on runoff and soil erosion in the semiarid loess hilly area, China. J. Hydrol. 2007, 335, 247-258. [CrossRef]

8. Arabameri, A.; Pradhan, B.; Pourghasemi, H.R.; Rezaei, K. Identification of erosion-prone areas using different multi-criteria decision-making techniques and GIS. Geomat. Nat. Haz. Risk 2018, 9, 1129-1155. [CrossRef]

9. Sun, W.; Shao, Q.; Liu, J.; Zhai, J. Assessing the effects of land use and topography on soil erosion on the Loess Plateau in China. Catena 2014, 121, 151-163. [CrossRef]

10. Cerdà, A.; Keesstra, S.D.; Rodrigo-Comino, J.; Novara, A.; Pereira, P.; Brevik, E.; Giménez-Morera, A.; Fernández-Raga, M.; Pulido, M.; di Prima, S.; et al. Runoff initiation, soil detachment and connectivity are enhanced as a consequence of vineyards plantations. J. Environ. Manag. 2017, 202, 268-275. [CrossRef]

11. Dabral, P.P.; Baithuri, N.; Pandey, A. Soil erosion assessment in a hilly catchment of north eastern India using USLE, GIS and remote sensing. Water Resour. Manag. 2008, 22, 1783-1798. [CrossRef]

12. Singh, O.; Singh, J. Soil Erosion Susceptibility Assessment of the Lower Himachal Himalayan Watershed. J. Geol. Soc. India 2018, 92, 157-165. [CrossRef]

13. Odunuga, S.; Ajijola, A.; Igwetu, N.; Adegun, O. Land susceptibility to soil erosion in Orashi Catchment, Nnewi South, Anambra State, Nigeria. Proc. Int. Assoc. Hydrol. Sci. 2018, 376, 87-95. [CrossRef]

14. de Vente, J.; Poesen, J.; Verstraeten, G.; Govers, G.; Vanmaercke, M.; van Rompaey, A.; Arabkhedri, M.; Boix-Fayos, C. Predicting soil erosion and sediment yield at regional scales: Where do we stand? Earth-Sci. Rev. 2013, 127, 16-29. [CrossRef]

15. Vandekerckhove, L.; Poesen, J.; Oostwoud-Wijdenes, D.; Nachtergaele, J.; Kosmas, D.; Roxo, M.J.; Figueiredo, T.D. Thresholds for gully initiation and sedimentation in Mediterranean Europe. Earth Surf. Process. Landf. 2000, 1201-1220. [CrossRef]

16. Directive 2000/60/EC of the European Parliament and of the Council of 23 October 2000 Establishing a Framework for Community Action in the Field of Water Policy. Available online: https:/ / eur-lex.europa.eu/eli/dir/2000/60/oj (accessed on 21 October 2019).

17. Pacific Southwest Inter-Agency Committee (PSIAC). Report of the Water Management Sub-Committee. Sedimentation Task Force; ASCE: Arizona, UT, USA, 1968; Volume 10, Chapter 98; p. 29.

18. Wischmeier, W.H.; Smith, D.D. Predicting Rainfall Erosion Losses: A Guide to Conservation Planning. In Agriculture Handbook No. 537; USDA: Washington, DC, USA, 1978; p. 66. Available online: https://naldc.nal.usda.gov/download/CAT79706928/PDF (accessed on 7 November 2018).

19. Renard, K.G.; Foster, G.R.; Weesies, G.A.; McCool, D.K.; Yoder, D.C. Predicting Soil Erosion by Water: A Guide to Conservation Planning with the Revised Universal Soil Loss Equation (RUSLE); U.S. Department of Agriculture: Washington, DC, USA, 1997; Volume 703, p. 407.

20. Shen, Z.Y.; Gong, Y.W.; Li, Y.H.; Hong, Q.; Xu, L.; Liu, R.M. A comparison of WEPP and SWAT for modeling soil erosion of the Zhangjiachong Watershed in the Three Gorges Reservoir Area. Agric. Water Manag. 2009, 96, 1435-1442. [CrossRef]

21. Morgan, R.P.C.; Quinton, J.N.; Smith, R.E.; Govers, G.; Poesen, J.W.A.; Auerswald, K.; Chisci, G.; Torri, D.; Styczen, M.E. The European soil erosion model (EUROSEM): A dynamic approach for predicting sediment transport from fields and small catchments. Earth Surf. Proc. Land. 1998, 23, 527-544. [CrossRef] 
22. Amiri, F. Estimate of erosion and sedimentation in semi-arid basin using empirical models of erosion potential within a geographic information system. Air Soil and Water Res. 2010, 3, 37. [CrossRef]

23. Merritt, W.; Letcher, R.; Jakeman, A.J. A review of erosion and sediment transport models. Environ. Model. Softw. 2003, 18, 761-799. [CrossRef]

24. Goetz, J.; Brenning, A.; Petschko, H.; Leopold, P. Evaluating machine learning and statistical prediction techniques for landslide susceptibility modeling. Comput. Geosci. 2015, 81,1-11. [CrossRef]

25. Märker, M.; Pelacani, S.; Schröder, B. A functional entity approach to predict soil erosion processes in a small Plio-Pleistocene Mediterranean catchment in Northern Chianti, Italy. Geomorphology 2011, 125, 530-540. [CrossRef]

26. Zakerinejad, R.; Märker, M. Prediction of gully erosion susceptibility using detailed terrain analysis and Maximum Entropy Modeling: A case study in the Mazayejan plain, Southwest Iran. Geogr. Fis. Din. Quat. 2014, 37, 67-76.

27. Lombardo, L.; Cama, M.; Conoscenti, C.; Marker, M.; Rotigliano, E. Binary logistic regression versus stochastic gradient boosted decision trees in assessing landslide susceptibility for multiple-occurring landslide events: Application to the 2009 storm event in Messina (Sicily, southern Italy). Nat. Hazards 2015, 79, 1621-1648. [CrossRef]

28. Igwe, O.; John, U.I.; Solomon, O.; Obinna, O. GIS-based gully erosion susceptibility modeling, adapting bivariate statistical method and AHP approach in Gombe town and environs Northeast Nigeria. Geoenviron. Disasters 2020, 7, 32. [CrossRef]

29. Corine Land Cover (CLC) Database; Chief Inspectorate for Environmental Protection \& Institute of Geodesy and Cartography: Warszawa, Poland, 2006. Available online: http:/ / clc.gios.gov.pl/ (accessed on 19 April 2017).

30. Heymann, Y.; Steenmans, C.; Croisille, G.; Bossard, M. CORINE Land Cover. Technical Guide; Office for Official Publications of the European Communities: Luxembourg, 1994; p. 136.

31. Kondracki, J. Geografia Regionalna Polski; Wydawnictwo Naukowe PWN: Warszawa, Poland, 2002; p. 440.

32. Babiński, Z. Wspótczesne Procesy Korytowe Dolnej Wisty; Institute of Geography and Spatial Organization Polish Academy of Sciences: Warszawa, Poland, 1992; p. 178.

33. Woś, A. Klimat Polski; Wyd. Naukowe PWN: Warszawa, Poland, 1999; p. 301.

34. Gaździcki, J. Systemy Informacji Przestrzennej; Polskie Przedsiębiorstwo Wydawnictw Kartograficznych: Warszawa-Wrocław, Poland, 1990; p. 183.

35. Szypuła, B. Cyfrowe Modele Terenu Jako Główne Źródło Danych w Geomorfometrii. In Numeryczne Modele Terenu w Kartografii; Żyszkowska, W., Spallek, W., Eds.; Uniwersytet Wrocławski: Wrocław, Poland, 2010; pp. 110-121.

36. Bossard, M.; Feranec, J.; Ot'ahel', J. Corine Land Cover Technical Guide-Addendum; European Environment Agency: Copenhagen, Denmark, 2000.

37. Conrad, O.; Bechtel, B.; Bock, M.; Dietrich, H.; Fischer, E.; Gerlitz, L.; Wehberg, J.; Wichmann, V.; Böhner, J. System for Automated Geoscientific Analyses (SAGA) v. 2.1.4. Geosci. Model Dev. 2015, 8, 1991-2007. [CrossRef]

38. Rahmati, O.; Tahmasebipour, N.; Haghizadeh, A.; Pourghasemi, H.R.; Feizizadeh, B. Evaluation of different machine learning models for predicting and mapping the susceptibility of gully erosion. Geomorphology 2017, 298, 118-137. [CrossRef]

39. Koethe, R.; Lehmeier, F. SARA—System zur Automatischen Relief-Analyse. User Manual, 2nd ed.; Dept. of Geography, University of Goettingen: Goettingen, Germany, 1996; unpublished.

40. Wood, J. Geomorphometry in LandSerf. In Geomorphometry: Concepts, Software, Applications. Developments in Soil Science; Hengl, T., Reuter, H.I., Eds.; Elsevier: Amsterdam, The Netherlands, 2009; Volume 33, pp. 333-349.

41. Freeman, G.T. Calculating catchment area with divergent flow based on a regular grid. Comput. Geosci. 1991, 17, 413-422. [CrossRef]

42. Moore, I.D.; Grayson, R.B.; Ladson, A.R. Digital terrain modelling: A review of hydrogical, geomorphological, and biological applications. Hydrol. Process. 1991, 5, 3-30. [CrossRef]

43. Marchi, L.; Fontana, G.D. GIS morphometric indicators for the analysis of sediment dynamics in mountain basins. Environ. Geol. 2005, 48, 218-228. [CrossRef]

44. Zevenbergen, L.W.; Thorne, C.R. Quantitative analysis of land surface topography. Earth Surf. Process. Landf. 1987, 12, 47-56. [CrossRef]

45. Sørensen, R.; Zinko, U.; Seibert, J. On the calculation of the topographic wetness index: Evaluation of different methods based on field observations. Hydrol. Earth Syst. Sci. Discuss. Eur. Geosci. Union 2005, 2, 1807-1834. [CrossRef]

46. Phillips, S.J.; Anderson, R.P.; Schapire, R.E. Maximum entropy modeling of species geographic distributions. Ecol. Model. 2006, 190, 231-259. [CrossRef]

47. Phillips, S.J.; Dudik, M. Modeling of species distributions with Maxent: New extensions and a comprehensive evaluation. Ecography 2008, 31, 161-175. [CrossRef]

48. Bosino, A.; Giordani, P.; Quénéhervé, G.; Maerker, M. Assessment of calanchi and rill-interrill erosion susceptibilities using terrain analysis and geostochastics: A case study in the Oltrepo Pavese, Northern Apennines, Italy. Earth Surf. Process. Landf. 2020, 45, 3025-3041. [CrossRef]

49. Maerker, M.; Bolus, M. Explorative Spatial Analysis of Neandertal Sites using Terrain Analysis and Stochastic Environmental Modelling. J. Geogr. Inf. Sci. 2018, 6, 21-38. [CrossRef]

50. Szatten, D.; Więcław, M. Solar Climate Features Taking into Account the Morphometric Conditions of the Area and the Possibility of Using Them in Heliotherapy on the Example of the Cieplice and Kołobrzeg Health Resorts (Poland). Atmosphere 2021, 12, 383. [CrossRef] 
51. Rahmati, O.; Pourghasemi, H.R.; Melesse, A.M. Application of GIS-based data driven random forest and maximum entropy models for groundwater potential mapping: A case study at Mehran Region, Iran. Catena 2016, 137, 360-372. [CrossRef]

52. Kornejady, A.; Ownegh, M.; Bahremand, A. Landslide susceptibility assessment using maximum entropy model with two different data sampling methods. Catena 2017, 152, 144-162. [CrossRef]

53. Chen, W.; Pourghasemi, H.R.; Naghibi, S.A. Prioritization of landslide conditioning factors and its spatial modeling in Shangnan County, China using GIS-based data mining algorithms. Bull. Eng. Geol. Environ. 2017, 77, 611-629. [CrossRef]

54. Chung, C.F.; Fabbri, A.G. Validation of spatial prediction models for landslide hazard mapping. Nat. Hazards 2003, 30, 451-472. [CrossRef]

55. Hosmer, D.W.; Lemeshow, S. Applied Logistic Regression, 3rd ed.; Wiley: New York, NY, USA, 2000; p. 528.

56. Erdogan, E.H.; Erpul, G.; Bayramin, I. Use of USLE/GIS methodology for predicting soil loss in a semiarid agricultural watershed. Environ. Monit. Assess. 2007, 131, 153-161. [CrossRef]

57. El Jazouli, A.; Barakat, A.; Ghafiri, A.; El Moutaki, S.; Ettaqy, A.; Khellouk, R. Soil erosion modeled with USLE, GIS, and remote sensing: A case study of Ikkour watershed in Middle Atlas (Morocco). Geosci. Lett. 2017, 4, 25. [CrossRef]

58. Szatten, D.; Habel, M.; Pellegrini, L.; Maerker, M. Assessment of Siltation Processes of the Koronowski Reservoir in the Northern Polish Lowland Based on Bathymetry and Empirical Formulas. Water 2018, 10, 1681. [CrossRef]

59. Kruk, E.; Klapa, P.; Ryczek, M.; Ostrowski, K. Influence of DEM Elaboration Methods on the USLE Model Topographical Factor Parameter on Steep Slopes. Remote Sens. 2020, 12, 3540. [CrossRef]

60. Panagos, P.; Meusburger, K.; Ballabio, C.; Borrelli, P.; Alewell, C. Soil erodibility in Europe: A high-resolution dataset based on LUCAS. Sci. Total Environ. 2014, 479-480, 189-200. [CrossRef] [PubMed]

61. Panagos, P.; Borrelli, P.; Meusburger, K.; Alewell, C.; Lugato, E.; Montanarella, L. Estimating the soil erosion cover-management factor at the European scale. Land Use Policy 2015, 48, 38-50. [CrossRef]

62. Panagos, P.; Borrelli, P.; Meusburger, K.; van der Zanden, E.H.; Poesen, J.; Alewell, C. Modelling the effect of support practices (P-factor) on the reduction of soil erosion by water at European scale. Environ. Sci. Policy 2015, 51, 23-34. [CrossRef]

63. Bosino, A.; Omran, A.; Maerker, M. Identification, characterisation and analysis of the Oltrepo Pavese calanchi in the Northern Apennines (Italy). Geomorphology 2019, 340, 53-66. [CrossRef]

64. Saha, S.; Gayen, A.; Pourghasemi, H.R.; Tiefenbacher, J.P. Identification of soil erosion-susceptible areas using fuzzy logic and analytical hierarchy process modeling in an agricultural watershed of Burdwan district, India. Environ. Earth Sci. 2019, 78, 649. [CrossRef]

65. Arabameri, A.; Asadi Nalivan, O.; Saha, S.; Roy, J.; Pradhan, B.; Tiefenbacher, J.P.; Thi Ngo, P.T. Novel Ensemble Approaches of Machine Learning Techniques in Modeling the Gully Erosion Susceptibility. Remote Sens. 2020, 12, 1890. [CrossRef]

66. Conoscenti, C.; di Maggio, C.; Rotigliano, E. Soil erosion susceptibility assessment and validation using a geostatistical multivariate approach: A test in Southern Sicily. Nat. Hazards 2008, 46, 287-305. [CrossRef]

67. Cama, M.; Schillaci, C.; Kropáček, J.; Hochschild, V.; Bosino, A.; Märker, M. A Probabilistic Assessment of Soil Erosion Susceptibility in a Head Catchment of the Jemma Basin, Ethiopian Highlands. Geosciences 2020, 10, 248. [CrossRef]

68. Szatten, D.; Habel, M. Effects of Land Cover Changes on Sediment and Nutrient Balance in the Catchment with Cascade-Dammed Waters. Remote Sens. 2020, 12, 3414. [CrossRef]

69. Szumińska, D. Przebieg Odpływu w Zlewni Wdy na tle Zmian Intensywności Użytkowania Wód w Drugiej Połowie XX Wieku; Kazimierz Wielki University Press, Wdecki Park Krajobrazowy: Bydgoszcz-Osie, Poland, 2014; p. 175.

70. Babiński, Z. Hydromorphological consequences of regulating the lower Vistula, Poland. Regul. Rivers Res. Manag. 1992, 7, 337-348. [CrossRef]

71. Gierszewski, P.; Habel, M.; Szmańda, J.; Luc, M. Evaluating effects of dam operation on flow regimes and riverbed adaptation to those changes. Sci. Total. Environ. 2020, 710, 136202. [CrossRef] [PubMed]

72. Habel, M. Dynamics of the Vistula River Channel Deformations Downstream of Włocławek Reservoir; Kazimierz Wielki University Press: Bydgoszcz, Poland, 2013; p. 144.

73. Conforti, M.; Aucelli, P.P.C.; Robustelli, G.; Scarciglia, F. Geomorphology and GIS analysis for mapping gully erosion susceptibility in the Turbolo stream catchment (Northern Calabria, Italy). Nat. Hazards 2011, 56, 881-898. [CrossRef]

74. Pournader, M.; Ahmadi, H.; Feiznia, S.; Karimi, H.; Peirovan, H.R. Spatial prediction of soil erosion susceptibility: An evaluation of the maximum entropy model. Earth Sci. Inform. 2018, 11, 389-401. [CrossRef]

75. Zabihi, M.; Mirchooli, F.; Motevalli, A.; Darvishan, A.K.; Pourghasemi, H.R.; Ali Zakeri, M.; Sadighi, F. Spatial modelling of gully erosion in Mazandaran Province, northern Iran. Catena 2018, 161, 1-13. [CrossRef] 